
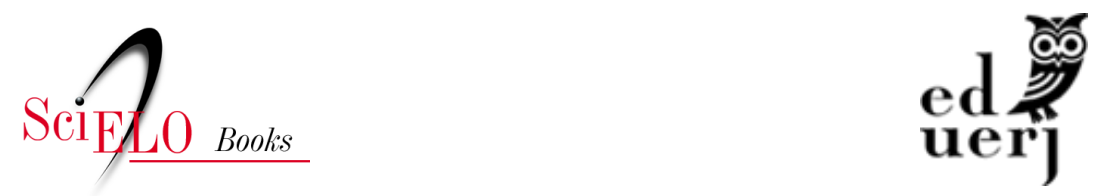

\title{
Capítulo I - Gerações docentes em trânsito e o governo da instrução: trama de relações oficiais e oficiosas
}

\author{
Angélica Borges
}

\section{SciELO Books / SciELO Livros / SciELO Libros}

BORGES, A. Gerações docentes em trânsito e o governo da instrução: trama de relações oficiais e oficiosas. In: A urdidura do magistério primário na Corte Imperial: um professor na trama de relações e agências [online]. Rio de Janeiro: EDUERJ, 2021, pp. 51-128. ISBN: 978-65-87949-20-8. https://doi.org/10.7476/9786587949208.0003.

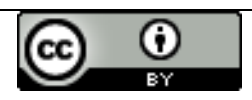

All the contents of this work, except where otherwise noted, is licensed under a Creative Commons Attribution 4.0 International license.

Todo o conteúdo deste trabalho, exceto quando houver ressalva, é publicado sob a licença Creative Commons Atribição 4.0.

Todo el contenido de esta obra, excepto donde se indique lo contrario, está bajo licencia de la licencia Creative Commons Reconocimento 4.0. 


\section{Capítulo I}

\section{Gerações docentes em trânsito e o governo da instrução: trama de relaçóes oficiais e oficiosas}

Em 1836, aos 18 anos de idade, Pardal fazia uma de suas tentativas de iniciar o magistério em uma instituição do Estado. Solicitou sua admissão como mestre da Escola de Aprendizes do Arsenal. A resposta: "Por ora não tem lugar" (Correio Oficial, 22 out. 1836). No ano seguinte, pediu para ser admitido ao concurso da cadeira de primeiras letras de Inhaúma (Correio Oficial, 25 ago. 1837), acerca do qual não foi possível localizar mais informações. Em dezembro foi aprovado no concurso para a cadeira da freguesia de Santa Rita, dando início a uma longa carreira no magistério público. Embora tenha se aposentado em 1874, aos 56 anos de idade, ele continuou atuando no ofício, pelo menos até 1879 , e na cidade, por mais alguns anos. Notas de jornais registram sua atuação como mesário das eleições na freguesia de Engenho Novo em 1886 (Diário de Noticias e $O$ Paiz, 15 jan. 1886).

Como já assinalado, no âmbito da atividade docente, a longa trajetória de Pardal o permitiu acompanhar muitas mudanças relacionadas ao processo de escolarização engendrado pelo governo e por outras instâncias que atuavam no ramo da instrução na sociedade, que abarcavam políticas, questões pedagógicas e profissionalização do ofício. Em razão disso, Pardal consiste em uma figura com experiências e agências diversas, que pode alinhavar uma forma de contar a trajetória da profissão nas escolas públicas no Município da Corte. Ao longo do período em que Pardal exerceu o magistério público, fosse na escola primária, no Colégio de D. Pedro II, no Instituto Comercial ou na direção das escolas municipais, também o fizeram outros mais de 170 professores públicos de primeiras letras na Corte, conforme podemos observar nos apêndices 1 e 2. 
Por meio das fontes pesquisadas, foi possível saber que, em 1837, entraram com Pardal mais oito professores e professoras nas escolas públicas da Corte. Uma delas, Francisca de Paula e Lima, assumiu a cadeira na mesma freguesia que ele, a de Santa Rita, e por vezes chegaram a trabalhar muito perto um do outro. A proximidade com Francisca era geográfica e também temporal. Ela foi jubilada na mesma década que Pardal, apenas três anos antes, em 1871, contra sua vontade. Por isso, tornou-se caso citado no Manifesto dos Professores de 1871, que teve como um dos signatários seu colega de freguesia e de tempo de experiência. Em encontros e desencontros no decorrer de suas trajetórias individuais e coletivas, Pardal, Francisca e outros nos dão a ver um conjunto de relações estabelecidas, entre eles, o governo e a cidade.

Neste capítulo, analiso aspectos que envolvem o conjunto e o trânsito de professores que atuaram no mesmo período que o professor Pardal, acompanhando os movimentos inerentes à profissão na época, de teor jurídico, político e social, bem como as posturas e tensões compartilhadas ou não, na heterogênea corporação de professores públicos da Corte. Para tanto, procuro pensar, ao longo do tempo de atuação de Pardal e de sua trajetória, quais foram as mudanças do âmbito do governo da instrução, como ordens, orientações, decretos e reformas que afetaram o exercício docência, e as relações entre o professor público, imbuído de civilizar a nação via escola, e o governo que o seleciona, nomeia, fiscaliza, exonera e jubila. Ambos exerciam poderes distintos, porém conectados e mutuamente comprometidos numa relação que pode ser desigual, mas cujos efeitos e agências não podem ser desprezados na configuração do ofício.

Nesse processo, em cerca de quatro décadas de atuação na instrução pública, Pardal pôde acompanhar muitas transformações e resistências quanto ao aspecto jurídico do "governo da instrução". Entre leis e decretos de abrangências distintas, que atingiram direta ou indiretamente a instrução, quando Pardal entrou em exercício no magistério primário estavam em vigor a Lei Geral de Ensino de 1827, a Lei das Câmaras Municipais de 1828, o Ato Adicional de 1834 e as "Providências e determinações sobre as Escolas de Primeiras Letras desta Corte e Município" de 1836 que criou o cargo de diretor das escolas. No âmbito provincial, havia também o decreto de criação da Escola Normal de Niterói, em 1835.

Nos anos que se seguiram, o Decreto n. 346 de 1844 regulou os trabalhos da Secretaria de Estado dos Negócios do Império, o Decreto n. 440 de 1845 organizou os concursos públicos de professores de primeiras letras e o Decreto de 
1. ' de agosto de 1846 instituiu juridicamente o "professor-substituto". Na década de 1850, situa-se o Regulamento de 1854, assim como o Regimento Interno das Escolas de 1855. Em 1872, foi estabelecido o Regulamento das Conferências Pedagógicas; em 1877, outro Regimento Interno para as escolas; e em 1879, ano em que Pardal pede demissão do cargo de diretor das escolas municipais dias após ser reintegrado à função, ocorre a Reforma Leôncio de Carvalho. Em 1880, começaria a funcionar a Escola Normal da Corte, criada anos antes por decreto de 1876.

O ordenamento jurídico ao qual a instrução na Corte foi submetida no decorrer do Império tratou de tomar práticas existentes ou tradicionais nas escolas (Schueler, 2002 e Villela, 2002a) e inseri-las em um regime disciplinar por meio de normas que buscavam regulamentar tempos, espaços, materialidades, métodos e sujeitos - aqueles a quem se destinava, os que deviam executar e os que deviam fiscalizar a execução.

Diante da emergência de várias questões concernentes à ideia de tradição, também optei por trabalhar com os conceitos de tradição discutidos por Hobsbawm (2002) e por Burke (2007), sem, no entanto, deixar de compreender as ações do Estado como parte dos mecanismos de "governamentalidade" (Foucault, 2006). Dessa maneira, pretendo dar destaque ao modo como os docentes operaram com a tradição e com a inovação, transitando pela "transmissão", "negociação", "tradução", "bricolagem”, "recepção" (Burke, 2007) ou mesmo resistência, mostrando os saberes, práticas e experiências que estavam em jogo nas relações que se estabeleciam - entre professores, demais membros da sociedade e governo - durante a definição e funcionamento de políticas voltadas para a instrução.

Hobsbawm opera com um conceito de "tradição inventada" que inclui as tradições "realmente inventadas" e formalmente institucionalizadas, bem como "as que surgiram de maneira mais difícil de localizar num período limitado e determinado de tempo - às vezes coisa de poucos anos apenas - e se estabeleceram com enorme rapidez" (2002, p. 9). A tradição inventada tem a ver com "um conjunto de práticas, normalmente reguladas por regras tácita ou abertamente aceitas" (2002, p. 9) e que pretende desenvolver certos valores e normas por meio da repetição e continuidade em relação ao passado, utilizando "a história como legitimadora de ações e como cimento de coesão grupal” (p. 21). Dessa forma, a invenção de tradições consiste em um processo de formalização e ritualização que, ao se referir ao passado, pode se dar pela imposição de repetição. Segundo Vidal 
(2005), tais tipos de práticas "asseguram um certo corporativismo e conferem ao magistério um locus identitário” (p. 131).

Desse modo, colocam-se duas questões. A primeira, o ordenamento jurídico não impediu que práticas - algumas das quais impregnadas de tradições - fossem toleradas ao arrepio da lei, enquanto fosse possível: escravizados e crianças não vacinadas frequentando a escola; ensino misto no lugar do simultâneo instituído em 1854; escolas de meninas onde estudavam meninos; aulas em um turno quando deveriam ocorrer em dois. Essa tensão entre as normas e as práticas ajuda a apreender o cenário de discussóes, questionamentos e o posicionamento daqueles que atuavam diretamente no funcionamento escolar, os professores. No entanto, debates e divergências em torno da escolarização de escravizados, método de ensino e políticas sanitárias mostram a inexistência de um consenso, mas também a agência de professores que se expressava na escola.

A segunda - que tem relação com a primeira -, as leis e normas, em certa medida, também foram instituídas ao "arrepio de práticas pedagógicas" que circulavam entre os professores, que se traduziam nas discordâncias, resistências, negociações ou interpretações intencionalmente enviesadas que os sujeitos apresentavam em relação às normas que deviam seguir. Tal aspecto se articula com as problematizações em torno do conceito de tradição trazidas por Burke (2007) e que tem a ver com "o contraste entre as constantes mudanças e inovações do mundo moderno e a tentativa de estruturar de maneira imutável e invariável ao menos alguns aspectos da vida social" (Hobsbawm, 2002, p. 10).

Portanto, procuro articular, no âmbito das tradições (Hobsbawm, 2002 e Burke, 2007), tanto as ações do governo quanto as dos sujeitos escolares por meio de um jogo de análise que visa compreender as estratégias de normalização por parte dos agentes do governo (Foucault, 2006) e pelos próprios professores, mas também as modalidades de resistência, ou agência de resistência, mobilizadas por estes mesmos indivíduos (Bhabha, 1998).

Porém, isso não significa que nas relações entre governo - via normas jurídicas, autoridades, agentes de fiscalização e políticas -, e professores houvesse necessariamente uma situação permanente de tensão e de resistência, por estarem em posições diferentes. Governos e professores, tanto no que diz respeito às tradições quanto às inovações, também poderiam compartilhar ideias e agir em cooperação, de forma contínua ou provisória, parcial ou totalmente, de acordo com suas posições no cenário político e com os governantes. 
Em vista disso, para examinar o aparato jurídico que incidiu sobre o exercício da profissão na Corte ao longo do século XIX, optei por levantar um conjunto de aspectos referentes à normatização em consonância com a trajetória de Pardal. Considerando, portanto, os limites da abordagem, a análise se organiza em três movimentos temporais, ou três ciclos. Porém, estão assim dispostos mais para organizar a reflexão do que para estabelecer marcos, não sendo este último o intuito do estudo.

O primeiro momento compreende os anos que precedem a nomeação de Pardal em 1837, passando pela sua formação na Academia Imperial de Belas Artes até o período que antecede a Reforma Couto Ferraz. Esse momento de regulamentação dispersa, por meio de decretos e portarias baixados de acordo com as demandas, é intensamente marcado pela existência de relações institucionais que poderíamos chamar de "artesanais", na esteira da ideia da "prática artesanal” do ofício colocada por Schueler (2002), ou pouco profissionais. Nesse ínterim, abordo três questões que intervêm na configuração da instrução pública naquele momento e que estavam mutuamente comprometidas: os embates entre o governo e a Câmara Municipal, o provimento das cadeiras de primeiras letras e a instituição do ensino mútuo.

O segundo tem a ver com os processos de implementação da Reforma de 1854 , muito debatida pelos historiadores, que conferem um reordenamento jurídico à instrução. Tais processos também permitem estabelecer, segundo Schueler (2002) e Villela (2002a), um movimento de "funcionarização" dos professores da Corte, que não ocorreu sem a participação dos próprios docentes, posto que estava em andamento antes da reforma. Isso não quer dizer que o Regulamento inaugurou uma nova forma de relação, mas contribuiu significativamente para um processo de estabelecimento de relações institucionais mais burocratizadas/ profissionais - vinculado também à "funcionarização" mencionada. Tal burocracia foi centralizada na Inspetoria Geral de Instrução Primária e Secundária da Corte (IGIPSC) e colaborou para produção de um "habitus" profissional. Nesse sentido, levanto questões em torno das etapas burocráticas que compõem o ofício de professor público primário na Corte, começando pela do adjunto e passando pelas nomeações, remoções, exonerações e jubilações, bem como a morte em serviço. As entradas, saídas e mudanças demonstram a dinâmica de procedimentos burocráticos, mas também mobilizam sujeitos, tradições, ideias pedagógicas, jogos políticos e interesses pessoais, assim como agências docentes. 
O terceiro momento abarca o período de uma contrapartida mais incisiva dos professores na relação com o governo. Conforme estudos de Villela (2002a), Schueler (2002) e Lemos (2006) foi um momento em que os professores se reconheceram enquanto categoria, mudando a forma de se relacionarem como governo, assumindo um corpo coletivo, uma agência coletiva. Dessa forma, procuro enfocar as Conferências Pedagógicas e os debates em torno do horário escolar.

As mudanças no modo como os professores se relacionavam com o governo, analisadas em três momentos, não constituem períodos estanques, nem evolutivos, mas interações propiciadas pelas diferentes maneiras dos sujeitos se apropriarem ou não das ordens legais.

\section{"Pede para ser admitido"}

O pedido de Pardal para ser admitido como professor na Escola do Arsenal, em 1836, sugere a hipótese de que o professor tinha a "necessária instrução" do ensino mútuo, uma vez que, segundo Bastos (1999), em tal escola era empregado o método. Segundo as fontes, na Escola de Primeiras Letras de Meninos de Santa Rita, Pardal aplicava o ensino mútuo. No Imperial Colégio de D. Pedro II, instituição em que começou a lecionar em 1839, dois anos após a fundação, ocupava a cadeira de desenho, a mesma que assumiu no Instituto Comercial da Corte, em 1857. No Colégio da Baronesa de Geslin, Pardal ensinava gramática da língua portuguesa e história pátria para as meninas desde 1868.

Como Pardal se tornou professor de primeiras letras - pelo método mútuo, depois pelo misto -, de gramática, caligrafia e desenho, aparecendo às vezes com a especificação desenho linear, figurado ou caligráfico? Não foi possível saber como o professor aprendeu o método mútuo. $\mathrm{O}$ ensino pelo método misto provavelmente foi se constituindo no fazer docente e com as mudanças nas normas oficiais. $\mathrm{O}$ mesmo pode ter ocorrido com o domínio do saber da gramática. Em nota de 1848, consta que Pardal havia sido nomeado examinador de gramática dos estudantes que iam se matricular na Aula de Comércio (Diário do Rio de Janeiro, 01 mar. 1848), o que denota que a imersão de Pardal na área já estava posta nos seus primeiros dez anos de carreira. Quanto ao ensino de desenho, durante boa parte da pesquisa não havia encontrado informações a respeito, até o momento da localização de um documento de matrícula dos empregados do 
Colégio de D. Pedro II que assinalava que ele era "premiado pela Academia de Belas Artes com medalha de ouro em pintura histórica”. ${ }^{6}$

\section{Formação premiada na Academia Imperial de Belas Artes}

O documento, portanto, indicava que Pardal tinha passagem pela Academia e que possuía alguma formação institucional que lhe conferia autoridade para o ensino de desenho. De posse de tal informação, busquei dados acerca da história da Academia para compreender que tipo de formação o professor poderia ter adquirido na instituição, bem como investigar a existência de documentos relativos ao "aluno Pardal". Para tanto, fiz uma procura por acervos onde estariam documentos referentes à Academia Imperial de Belas Artes. De tal modo, foi possível chegar ao Museu D. João IV da Escola de Belas Artes da UFRJ que conta com um importante acervo documental, desde os primeiros anos de funcionamento da Academia. Entre os materiais, encontram-se os livros de matrículas dos alunos, nos quais foi localizada a matrícula de Pardal, conforme podemos ver na imagem a seguir.

Figura 5 - Recorte de imagem extraída do Livro de Matrícula da AIBA de $1827-1831$

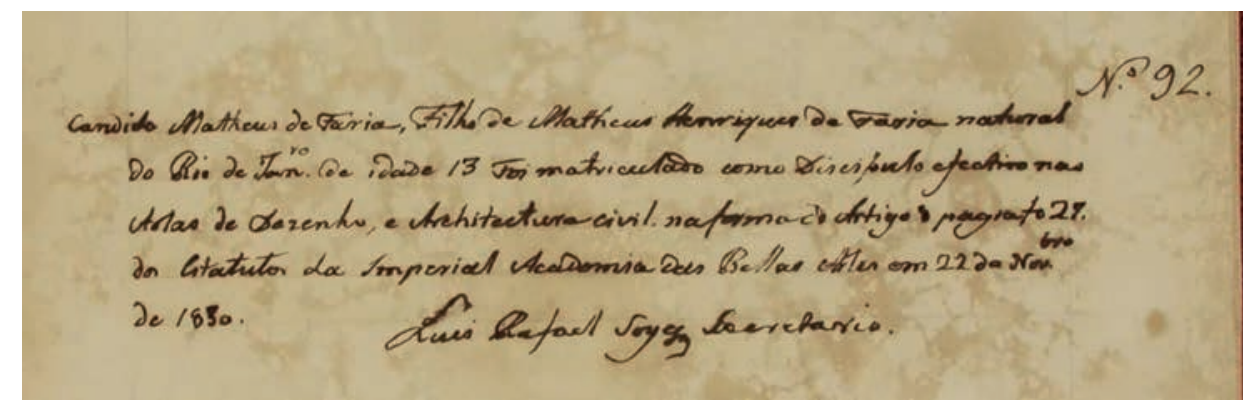

Fonte: Acervo do Museu D. João VI - EBA-UFRJ.

O pequeno texto traz várias informações interessantes a respeito do professor e da escola, como o fato dele não usar o sobrenome Pardal. Sobrenome

${ }^{6}$ Agradeço a Elizabeth Monteiro da Silva, bibliotecária do Colégio Pedro II, a gentileza de ter localizado e fotografado para mim a documentaçáo de Pardal nos arquivos do NUDOM na Unidade Centro do Colégio. 
que no interior da discussão a respeito das práticas de nomeação presente no capítulo II poderia não ser da família, mas de um apadrinhamento ou de uma pessoa de referência. Pardal foi matriculado em 22 de novembro de 1830 aos treze anos de idade - provavelmente incompletos - como discípulo efetivo nas aulas de Desenho e Arquitetura Civil. O período é marcado por tensões, disputas e várias mudanças de caráter político, pedagógico e institucional da Academia, conforme assinala Dias (2009).

Com uma emergência que remonta à vinda da "Missão Artística Francesa" ao Brasil, em 1816, à criação da Real Academia de Desenho, Pintura, Escultura e Arquitetura Civil, em 1820, e às disputas entre franceses e portugueses, a Academia Imperial de Belas Artes (AIBA) foi criada em 1824 e efetivamente estabelecida em 1826. Os estatutos mencionados no texto da matrícula de Pardal, de acordo com aviso n. 135 de 30 de setembro de 1826, teriam sido estabelecidos em 23 de novembro de 1820 (Dias, 2009). Dias relata que o português Henrique José da Silva, diretor da Academia, redigiu os estatutos a partir daqueles de 1820, mas, contrariando as expectativas de alguns, estabeleceu que o curso de desenho, com base nas leis de Aula Régia de Desenho e Arquitetura Civil de Lisboa, deveriam durar três anos, somente após o qual o aluno poderia frequentar as aulas de pintura, arquitetura e escultura, fato que desagradou aos franceses. No entanto, a regra também foi burlada pelos alunos e pelos professores franceses para igual desagrado do diretor. Segundo o Estatuto, a duração dos cursos na AIBA seria de cinco anos para os discípulos efetivos.

O 8. ${ }^{\circ}$ artigo a que se refere a matrícula de Pardal dizia respeito aos alunos, suas obrigações e diplomas. Pardal foi matriculado como "efetivo", em uma das duas classes de discípulos existentes:

Haverá duas Classes de Discípulos, uma das Classes será de Efetivos, por terem estes a obrigação de frequentarem todo o curso dos estudos a que se quiserem aplicar, a segunda Classe será de Discípulos Extraordinários; os primeiros serão matriculados, porem os segundos serão isentos desta cláusula por não terem obrigação de frequentar; estes lugares são destinados às pessoas adultas, e deleitantes que desejarem instruírem-se, e só para recreio cultivam as Belas Artes; mas devem igualmente requerer para serem admitidos?

7 Extraído da transcrição feita pelo professor Alberto Cipiniuk, a partir de um documento localizado no Arquivo Nacional do Rio de Janeiro, Caixa 6283. Disponível em http:// www.dezenovevinte.net/documentos/estatutos_1820.htm. Acesso em jul. 2014. 
Já o parágrafo 27 do mesmo artigo referia-se ao modo de efetuar a matrícula e à faixa etária "não se admitindo para Discípulos Efetivos senão os de idade de doze até quinze anos, o que se verificará pela certidão da idade que devem apresentar no ato da matrícula".

Pardal se matriculou no final do ano de 1830 e no ano seguinte começou o movimento de reforma na Academia. Em 1831, Debret, professor de pintura histórica, voltou para França. No Brasil permaneceram os dois últimos remanescentes da "Missão Francesa", Grandjean de Montigny e Félix-Émile Taunay, que, segundo Dias, foram fundamentais na reorganização dos estatutos da Academia. Félix-Émile Taunay assumiu o posto de secretário da AIBA e, posteriormente, em 1834 foi nomeado diretor da instituição, permanecendo no cargo por dezessete anos. Seu filho, Visconde de Taunay, é que viria a ser aluno de Pardal no Colégio de D. Pedro II, conforme já mencionado.

Ocorre, então, a redução da duração do curso de desenho de três para um ano, que incorpora também o estudo do modelo vivo, aulas de anatomia e tradução de obras didáticas. Os novos estatutos também passaram a exigir que alunos matriculados soubessem ler e escrever e que nos anos de formação demonstrassem domínio das línguas italiana e francesa, "indispensáveis à leitura dos tratados propostos na metodologia de ensino" (Dias, 2009, p. 60). O contato com línguas estrangeiras, mais especificamente a francesa, torna-se um dado relevante na medida em que se pretende entender as maneiras pelas quais Pardal obteve a aprendizagem da língua, que seria necessária muitos anos depois para a leitura do Cours d'études e o uso do sistema Rapet, de autoria de um francês cujas obras não estavam traduzidas.

O livro de matrícula de 1827 a 1831 apenas registra a entrada dos alunos. Mas, outro livro que compreende os anos de 1833 a 1844 traz também a listagem das turmas. Na primeira turma de desenho desse livro, Pardal não consta como aluno, mas iria aparecer numa anotação à parte na classe de Pintura Histórica em 1833, como tendo solicitado a matrícula.

Na turma de Pintura Histórica de 1834, ele aparece na listagem normal com o aviso de que foi admitido imediatamente de acordo com Ata da sessão de 18 de abril de 1833. A ata registrava a admissão de outro aluno na aula de Paisagem em atenção à decisão governo e em consideração aos talentos do requerente, concedendo-lhe a dispensa do primeiro ano de desenho e imediata matrícula na aula solicitada: "Mesma sorte teve a pretensão de Candido Matheus de Faria, o qual apresentou desenhos, a cuja vista, depois de leve discussão, o secretário teve autorização de compreendê-lo, desde já, na matrícula especial da aula de pintura 
histórica" (Ata de 18 abr. 1833). Pardal passou a constar então na turma de Pintura Histórica até 1835, disciplina na qual, segundo o livro de assentamento de professores do Colégio de D. Pedro II, ganhou a medalha de ouro. As datas sugerem, dessa forma, que o aluno Pardal completou os cinco anos inicialmente previstos para conclusão do curso.

Dias assinala que a ampliação dos cursos foi uma das alterações que ocorreram com a reforma. Os alunos de Pintura Histórica, por exemplo, do $1 .^{\circ}$ e $2 .^{\circ}$ anos, passaram a ter aula de osteologia, miologia e fisiologia das paixões e, com aprovação do governo em 21 de agosto de 1833, também passaram a ter aula de modelo vivo, o que segundo Dias tornava patente a incorporação dos modelos acadêmicos franceses na AIBA.

As normas de 1826 estabeleciam, "para promover a emulação tão louvável e necessária ao progresso, e adiantamento das Belas Artes”, dois prêmios ao fim de cada ano para cada uma das aulas, que corresponderiam à grande e à pequena medalha de ouro:

$32^{\circ}$ - Os concorrentes da primeira aula farão um desenho copiado, ficando à sua eleição a escolha do original que quiserem copiar. Os da aula de Pintura farão a cópia de um quadro do gênero a que se tiverem aplicado. Os da aula de Escultura farão o modelo de uma estátua, ou um grupo de três figuras, ou um baixo-relevo. E os de Arquitetura farão um desenho de qualquer edifício, cujo desenho deverá constar de Planta, Corte e Alçada.

$33^{\circ}$ - Os discípulos que nestas artes se distinguirem completando o curso acadêmico com aprovação de seus Professores terão além dos mencionados prêmios uma pensão para viajar por cinco anos [...]. Esta formalidade se seguirá nas Classes de Pintura, Escultura e Arquitetura das Belas Artes e terão a preferência nas Cadeiras das Aulas de Desenho que se estabelecerem nas Provincias do Império (grifos nossos).

Apesar dessas normas terem sido alteradas e do fato de tais premiações não terem sido postas em prática antes da reforma de 1831 (Dias, 2009), chama atenção o destaque que o livro de assentamentos do Colégio de D. Pedro II confere ao prêmio dado a Pardal, como se fosse um dos critérios usados para legitimar sua admissão na cadeira de desenho do Colégio, ${ }^{8}$ o que estaria de acordo

8 Presente na grade curricular que se alterou diversas vezes ao longo do Império, a cadeira de desenho foi assumida por Pardal em 1839, inicialmente na condição de interino, conforme registro do próprio colégio (Livro de Assentamentos), embora a pesquisa 
com a preferência prevista pelo antigo estatuto da AIBA. Dias afirma que, com a reforma de 1831, foram propostos prêmios trimensais, anuais e honoríficos que correspondiam, também, à grande e à pequena medalha de ouro, período em que Pardal teria recebido a medalha de ouro em Pintura Histórica.

A formação obtida na AIBA, o contato com outras línguas no interior da instituição e com a cultura artística de diversos países (vide o acervo de livros e obras de artes trazido para ser usado nas aulas) pode ter fornecido a Pardal uma rica experiência que se traduziu na inserção de aulas de desenho nas escolas por onde passou, apesar do ensino de desenho não estar previsto na Lei Geral de Ensino de 1827 e ser opcional no Regulamento da Corte de 1854. Assim como um investimento no domínio da língua francesa, que se fez necessária quando o professor se apropriou das ideias de Jean-Jacques Rapet na construção do programa de ensino das escolas municipais. Nesse sentido, cabe destacar que Pardal não foi o único professor público primário localizado nas listagens de alunos da AIBA. Foi possível observar o nome de Marcos Bernardino da Costa Passos na classe de desenho de 1834 e 1835 e o de João Pedro dos Santos Cruz que ganhou pequena medalha de ouro em desenho de ornato e figura em 1861 (O Correio da Tarde, $20 \mathrm{dez}$. 1861). Tal fato aponta para a possibilidade de outros professores também terem passado pela instituição, o que valeria uma maior investigação.

\section{"Faz ciente que..."}

Na década de 1830, Pardal se formou na AIBA, testemunhou a sua reforma, ingressou na regência da Escola Pública de Santa Rita e no Imperial Colégio de D. Pedro II. Também foi a década em que o Ato Adicional foi instituído (1834), bem como a Escola Normal da Província (1835) e as "Providências" para as escolas da Corte (1836). O processo de instauração de dispositivos legais, visando a normatização e regulamentação das atividades escolares, é constituído por brechas, itens não regulados e situações inesperadas. Dessa forma, forneceu margens para as agências docentes e atuações criativas, por meio das quais pro-

de Andrade (1999) inclua a aula de desenho a partir da reforma curricular de 1841. Nas várias reformas levantadas por Andrade, ora a cadeira estava dentro da grade obrigatória, ora como disciplina opcional - como, por exemplo, na reforma de $1862 \mathrm{em}$ que se tornou opcional, juntamente com música, dança e ginástica. Em alguns anos, o tipo de ensino de desenho foi especificado no Almanak Laemmert, como em 1844: "desenho caligráfico, linear e figurado". 
fessores fundamentavam sua discordância dos códigos jurídicos ou elaboravam as suas próprias normas, que poderiam soar até mesmo como procedimento previsto em lei. Esse é o caso da professora pública que colocou um anúncio no Correio Oficial de 21 de outubro de 1834 para comunicar que:

Figura 6 - Anúncio de provimento de cadeira de meninas

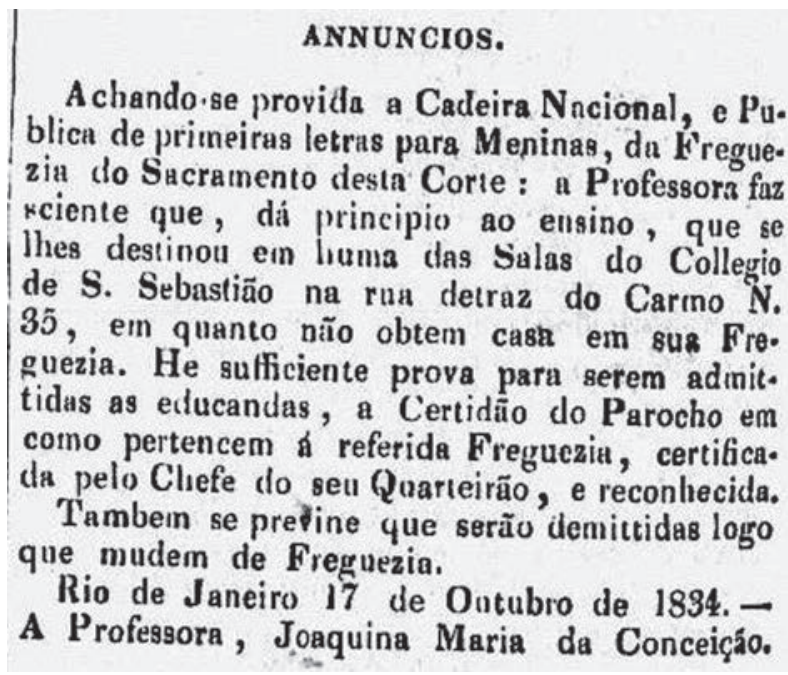

Fonte: Correio Oficial de 21 out. 1834, BN.

A professora da freguesia de Sacramento, Joaquina Maria da Conceição, "decretou" que só poderiam estudar na escola as meninas de sua freguesia, divulgando tal informação em um jornal como se fosse uma "portaria de matrícula". $\mathrm{O}$ ato da professora Joaquina coincide com o ano do Ato Adicional que facultou às províncias elaborarem suas próprias normas. Ironicamente, do mesmo modo, a professora apresentou uma postura de estabelecer suas próprias regras em seu "território" ou "inventar uma tradição".

Embora tenha sido considerada "abusiva" na época, a atitude da professora talvez não a caracterizasse como uma pessoa audaciosa e fizesse parte da rotina docente. No que concerne às leis e às normas, por viverem em um momento de processo de regulação legal em constituição no Império; pela ausência de regras oficiais para determinado quesitos; por questóes que iam se impondo no cotidiano e da urgência que iam adquirindo; além da autonomia proporcionada em 
tais circunstâncias, a atitude de Joaquina poderia sugerir ser comum que normas fossem criadas pelos próprios professores.

O chamado "abuso" não durou muito tempo. Logo em seguida, uma nota, em nome da Regência, informava que a exigência da dita professora não era procedente (Correio Oficial, 30 jan. 1835). Apresento o caso como exemplo para explicitar a delicada relação entre o processo de instituir leis e a mudança de práticas ordinárias.

Nesse sentido, a ideia de agências subalternas - manejadas por sujeitos ou grupos em situação de subordinação a outros - operada por Bhabha (1998) pode ajudar a redimensionar a atuação dos professores analisada ao longo do capítulo, diante de um processo de estatização da profissão. A agência subalterna negocia sua própria autoridade em um processo que Bhabha chama "de 'descosedura' iterativa e religação insurgente, incomensurável” (p. 269). Para Bhabha, trata-se de uma estratégia subversiva, nos espaços intersticiais e fronteiriços, que requer movimento e manobra, mas não continuidade e acumulação em termos de temporalidade, podendo tentar interrogar e rearticular "o 'inter-esse' da sociedade" em um processo de contestação dos símbolos de autoridade e de relocação e reinscrição dos sujeitos.

A tradição do uso de dispositivos jurídicos na instrução, no caso brasileiro, segundo Gondra (2001), pode remontar ao século XVI, com as normas da Companhia de Jesus. Contudo, para o autor,

[...] é no século XIX que se evidencia de modo mais vigoroso a explosão dos códigos jurídicos relativos à educação escolar, evidenciável já mesmo no processo de elaboração da primeira Constituição, iniciado em 1823, tendo continuidade até a vertiginosa quantidade de reformas educacionais produzidas no Brasil presentemente (2001, p. 2).

Por outro lado, Fonseca (2011) também dá destaque a um ciclo de intervenções a partir de 1759, quando Portugal iniciou um processo de atuação direta do Estado na educação por meio das "reformas pombalinas da educação", complementadas com outras normas ao longo das décadas seguintes. Assim, a segunda metade do século XVIII, segundo Fonseca, ficou marcada "como um momento particular de ações que visavam reorganizar diferentes dimensões de sua estrutura e administração" (p. 100), como parte de um esforço de modernização portuguesa para o Reino quanto para outras partes do Império. 
No âmbito dos processos de aplicação das leis no Império Brasileiro, o serviço responsável por garantir o cumprimento das normas, a fiscalização, promoveu tensões também entre instâncias de governo. A lei de 1827, embora não tenha esmiuçado o procedimento de fiscalização, definiu quem deveria executar o serviço: "Presidentes em Conselho, a quem pertence a fiscalização das escolas". Outra lei, datada de $1^{\circ}$ de outubro de 1828 , regulou o funcionamento das câmaras municipais e, por meio do artigo 70, atribuiu a elas a função de “inspeção sobre as escolas de primeiras letras".

Porém, a existência de leis e a atribuição de responsabilidade à Câmara Municipal relativas à inspeção das escolas parecem não ter surtido o efeito esperado na Corte. Diante disso, segundo Cardoso (1999), para impedir que fiscais e professores transgredissem ou contornassem a lei, o governo da Regência decidiu, em 5 de agosto de 1831, recomendar "à Sociedade Promotora da Instrução Elementar, no Rio de Janeiro, a colaborar com a inspeção das aulas de primeiras letras da Corte, 'um serviço de tanto interesse público, e tão análogo à sua patriótica instituição'.”(p. 126-127, grifo nosso). Cabe destacar que professores públicos primários, em exercício, também faziam parte da referida sociedade.

O governo continuou pressionando a Câmara no Rio de Janeiro e, dois anos depois, publicou uma portaria (Correio Oficial, 1836, n. 79) cobrando informações a respeito da sua atuação no assunto e indagando se seus fiscais estavam a inspecionar as escolas (Portaria de 4 de março de 1836). Aos fiscais da Câmara era atribuída a responsabilidade de fiscalizar diversos espaços e as escolas seriam mais uma entre tantas. Porém, nesse caso havia uma diferença, pois a escola pública em situação irregular não poderia ser "multada" - tal como ocorria no comércio, por exemplo, ramo bastante vigiado (Souza, 2007). O fato talvez causasse certo desinteresse dos fiscais em cumprir o papel de fiscalizar com o rigor que o governo esperava.

Apesar das constantes pressões que as fontes sugerem ter existido, o Correio Oficial denunciava que,

Tendo mostrado a experiência que, não obstante o haver-se confiado às Câmaras Municipais [...] a fiscalização das Escolas Primárias, não se tem conseguido o desejado progresso em favor da educação da Juventude; antes pelo contrário se há observado, no que respeita às Escolas de Primeiras Letras desta Corte e Município, um total desleixo e abandono sobre um tão interessante objeto, que aliás deve necessariamente produzir uma péssima influência sobre a cultura moral e intelectual 
da mocidade em seus destinos futuros; e sendo por isso da maior urgência ocorrer quanto antes ao remédio de tais males, estabelecendo uma eficaz e permanente fiscalização sobre a conduta, assiduidade, e mais obrigações dos Mestres das ditas escolas, dando-se-lhes uma norma fixa para regime do seu magistério, em harmonia com os princípios liberais e legislação em vigor, a fim de se preencherem os saudáveis fins da Carta de Lei de quinze de outubro de mil oitocentos e vinte e sete (28 mar. 1836, n. 69, grifo nosso).

A acusação dirigida à Câmara de tratar a instrução com "total desleixo e abandono" igualmente poderia indicar, mais do que um desinteresse da mesma, certa rivalidade ou revanche, diante das tentativas do governo de esvaziar os poderes municipais. O mesmo número do Correio Oficial que traz a denúncia pública as "Providências e determinações sobre as Escolas de Primeiras Letras desta Corte e Município, mandadas observar pelo Decreto desta data” (15 mar. 1836), que criou a função de diretor das escolas. Nomeado pelo Ministro do Império, o diretor tinha como função:

[... a fiscalização e inspeção das Escolas de Primeiras Letras desta Corte e Município, que lhe ficam subordinadas, e a respeito das quais fará observar, não só as presentes Providências e Determinações, mas também todas e quaisquer Instruções ou Ordens, que de futuro lhe forem pelo Governo transmitidas (Correio Oficial, 28 mar. 1836, n. 69).

Foi nomeado para o cargo Joaquim José da Silveira que havia sido, segundo a portaria de nomeação, ex-oficial maior da extinta mesa do Desembargo do Paço. Eram responsabilidades do diretor visitar escolas, averiguar o cumprimento das normas pelos professores, nomear substitutos, assistir aos exames e concursos de provimento de cadeiras. O Decreto também atribuía ao diretor o papel de "obrigar" os mestres a terem um livro de matrícula, rubricado por ele, constando os nomes dos alunos, datas de entrada e saída, pátria, idade, nome dos pais, com observações a respeito de comportamento, aplicação e progressos. Os professores também deveriam informar o método usado e o ensino das matérias previstas, bem como encaminhar os casos mais graves de insubordinação dos alunos ao diretor. Silveira ocupou o posto de diretor até 1854, ano da Reforma Couto Ferraz que criou o cargo de inspetor-geral na Corte, substituindo a figura do diretor. 
No entanto, apesar da lei que criava a autoridade do diretor, a celeuma acerca do papel da Câmara continuava, uma vez que a norma de 1836 não revogava a função fiscalizadora da Câmara na Corte. Um texto da sessão chamada "Artigos não oficiais" do Correio Oficial (1836, n. 74, p. 296, grifos nossos), assinada apenas por “G.", comenta o Decreto:

Que o Ministro e Secretário de Estado dos Negócios do Império, tenha a Inspeção suprema não só sobre os Estabelecimentos Gerais de instrução, nós perfeitamente entendemos isso, e com isso concordamos; mas que desça às miudezas de assistir a exames, de vigiar individualmente na maneira porque os professores cumprem com suas obrigações, no adiantamento dos alunos, e na avultada despesa que se faz neste ramo da Administração pública, é o que não nos parece compatível com os muitos, variados, e importantes objetos de que ele tem de ocupar-se em um país nascente como o nosso, onde pouco se tem feito, ou, para melhor dizer, tudo se acha ainda por fazer, do muito que é necessário para dar-se algum impulso a coisas de vital interesse, que tem estado esquecidas, ou inteiramente ignoradas. Mas, a câmara municipal, o que faz, perguntará alguém? Em verdade ela pouco ou nada pode fazer nesta matéria. Em primeiro lugar as Câmaras não são Corporações científicas, que possam exercer com vantagem a fiscalização que mais se deseja; em segundo lugar essa mesma fiscalização que exercem, elas a cometem a seus Fiscais, que menos ainda sabem, ou podem desempenhá-la. Para prova desta verdade basta refletir que no longo espaço de anos, decorrido desde a data da Lei que organizou as Escolas primárias, até hoje, ainda uma só reflexão útil não veio sobre este assunto ao Governo.

A crítica à incapacidade da Câmara de exercer a fiscalização por meio de seus "fiscais medíocres" e a alegação da existência de um ministro competente para executá-la, mas demasiado ocupado com os negócios do país para "descer às miudezas”, demonstra as tensões existentes entre as duas instâncias de poder e a discutível importância atribuída à instrução. Questões em torno do papel da Câmara na instrução pública iriam aparecer também na época da inauguração das escolas municipais dirigidas por Pardal na década de 1870, como veremos no capítulo IV.

A atuação da Câmara, embora fosse vista como ineficiente e realizada por fiscais que não "saberiam" desempenhá-la, como acusa o artigo, não se dava sem tensões e atritos com os professores, o que sugere que, se não fiscalizavam 
da forma esperada pelo governo, exerciam algum tipo de inspeção a ponto de incomodarem os mestres. ${ }^{9}$

A representação que o professor Estevão José Pires da freguesia de Guaratiba apresentou à Câmara (Correio Oficial, 25 ago. 1843), em que se queixa do fiscal por ele se negar a lhe dar o atestado de frequência, documento primordial para o recebimento do salário, demonstra a complicada relação imposta aos professores que ficavam submetidos às ingerências políticas de um indivíduo que ocupava um cargo considerado, pelas autoridades, inferior na escala do funcionalismo público, mas imbuído de poderes não subestimáveis.

As ingerências políticas poderiam deixar os professores em situações delicadas, como a denunciada por João José Pereira Sarmento, professor da freguesia de Santana (Diário do Rio de Janeiro, 14 jun. 1832). Sarmento acusou o fiscal de ser seu "gratuito inimigo" e de divulgar falsas informações ao seu respeito, pelas as quais o professor não queria sofrer "quebra de crédito e honra". Sarmento também aproveita a oportunidade para declarar não reconhecer o poder de fiscalização do dito fiscal e questiona sua autoridade lançando mão da própria legislação em vigor. Alega o fato da Lei de 1827 não atribuir ao cargo dele a inspeção das escolas e do artigo 70 da lei das câmaras municipais não "derrogar explicitamente" tal condição. A publicação da nota de defesa em jornal de grande circulação sugere que a repercussão das intrigas do "fiscal inimigo" poderia ter arranhado a imagem pública do professor na sociedade. Considerando que a moralidade era condição para exercer o ofício de ensinar, torna-se compreensível a preocupação do professor em tornar pública sua defesa por meio da imprensa.

Os debates em torno da estrutura administrativo-burocrática voltada para instrução também podem ser vistos no estudo de Alcântara (2014) para o caso de São Paulo. A autora assinala que a crença na racionalidade manifesta na burocracia dá sustentação à autoridade burocrática, que se estrutura a partir da hierarquia das atribuições e dos deveres oficiais. Nesse sentido, também se tornava necessário levar os professores a acreditarem na burocracia produzida em torno de sua atividade, como uma forma de conferir autoridade aos agentes que deveriam zelar pela própria burocracia.

Nesse processo de legislação e burocratização, até 1854, outras normas foram instituídas por meio de decretos e portarias. Algumas não tratavam dire-

9 Por um Aviso de 1844, a Câmara Municipal confiou a fiscalização, igualmente sem sucesso, aos párocos e juízes de paz, buscando "passar adiante" a função (Relatório do Ministro do Império de 1850, p. 13). 
tamente da instrução, mas se estendiam a ela, como o regulamento da Secretaria dos Negócios do Império, com uma versão de 1843 e outra de 1844. A versão estabelecida pelo Decreto n. 346 de 30 de março de 1844 organizava o expediente em seis sessões. A segunda era responsável pelas áreas da polícia, saúde, obras e pela instrução pública. Uma das atribuições dizia respeito a um dispositivo chave de governo: a estatística. $\mathrm{O}$ expediente da $2^{\text {a }}$ Sessão, definido pelo artigo 15 compreendia, entre outros incisos:

$2^{\circ} \mathrm{A}$ formação da Estatística de todas as Aulas, e Escolas, tanto públicas, como particulares, existentes no Império, à exceção das que se acharem a cargo de outro Ministério; demonstrando a respeito das primeiras o lugar, em que cada uma delas está colocada; a natureza, método, e livros do ensino; nome, estado, vencimento, assiduidade, e comportamento moral, e político do Professor; finalmente o número, e aproveitamento dos alunos em cada ano; e a respeito das particulares as mesmas circunstancias, com exclusão porém do vencimento dos Professores.

A “formação da estatística” tão cobrada à Câmara seria composta por números, mas também por informações sobre a escola e seu território, o ensino e materiais, e o professor, acerca do qual se deveria conhecer o comportamento moral e político. Apesar das complicadas condições de produção dos dados, provavelmente seriam utilizados pelo Ministro do Império em seus relatórios com discursos políticos cuidadosamente elaborados (Resende e Faria Filho, 2001 e Caldeira, 2008).

A observação prevista no artigo 15 para "formação da estatística”, em torno do comportamento político do professor, alerta para a existência de seu envolvimento com a política na primeira metade do século XIX e de uma preocupação por parte do governo. Munhoz (2012), no caso da $5^{\text {a Comarca de }}$ São Paulo (Paraná), investigou um professor de primeiras letras, Baptista Brandão, e sua posição afinada com as elites locais no momento da emancipação do Paraná. A trajetória de Brandão permitia, segundo a autora, analisar a presença dos professores primários em outros espaços, entre eles, o político, mas também “como a circulação por estes diferentes espaços e a acumulação de um repertório político-administrativo, legal e a destreza nas diferentes instituições imperiais foram significativas em sua experiência docente" (p. 140). 


\section{"A fim de ser provida na forma da lei"}

Tanto quanto a legislação, a fiscalização e a estatística, outra questão que demandava atenção era o próprio provimento da cadeira, para o qual era preciso prestar concurso, o que, para Garcia (2006), também estava ligado à profissionalização e à estatização do magistério. Cabe assinalar que, segundo Cardoso (1999), os termos "escola" e "cadeira" eram usados no mesmo sentido, "ou seja, uma aula pública de primeiras letras, ou uma aula de gramática latina, correspondia, cada uma, a uma cadeira específica, o que representava uma unidade escolar, uma escola” (p. 124). As aulas recorrentemente se davam na casa do próprio professor, portanto, as "escolas eram uma unidade de ensino com um professor” (Cardoso, 1999, p. 124).

A Lei Geral de 1827 definiu que os candidatos, com boa conduta e em gozo de seus direitos civis e políticos, seriam examinados publicamente perante os "Presidentes, em Conselho", sendo os "mais dignos" indicados ao governo para sua legal nomeação. O processo de normatização do concurso público passava pelo controle dos candidatos, mas também pela definição da banca examinadora. Problemas na sua composição renderam uma intervenção por parte da Regência, como indica a notificação publicada no Correio Oficial de 1835, n.123:

Illm. E Exm. Sr. - Tendo subido ao conhecimento da Regência a Representação do Diretor do Curso Jurídico dessa Cidade sobre a exigência, que V. Ex. Ihe fez, não só de Professores de Preparatórios, mas até de Lentes Substitutos, para servirem de Examinadores de Primeiras Letras no Concurso que tivera lugar no dia 6 do mês passado: manda a Mesma regência, em Nome do Imperador, declarar-lhe que, não sendo da profissão de tais pessoas o ensino de Primeiras Letras, nem são próprias, e nem podem ser obrigadas, quando voluntariamente não queiram prestar-se. Deus guarde V. Ex. Palácio do Rio de Janeiro em 20 de maio de 1835. - Joaquim Vieira da Silva e Souza. - Rafael Tobias de Aguiar.

Interessante observar que Rafael Tobias de Aguiar era paulista e, enquanto membro do Conselho da Presidência da Província de São Paulo na década de 1820, propôs a adoção do ensino mútuo nas escolas elementares (Hilsdorf, 1999). Considerado por Hilsdorf (1999) como parte das fileiras de liberais e ilustrados paulistas dos anos 1820 e 1830, sua presença na Corte pode ter ocorrido no intervalo entre seus dois mandatos na presidência da Província de São Paulo. 
A notificação do governo da Regência, nesse sentido, funcionaria como uma orientação normativa na organização das bancas, ao alertar que não eram “próprias” pessoas cuja profissão não fosse o ensino de primeiras letras. No entanto, por outro lado, a notificação concluía com a frase "quando voluntariamente não queiram prestar-se”, o que também era uma forma de permitir a participação dos interessados sem atuação no ensino primário.

Do mesmo modo que o Correio Oficial anunciava a realização de concursos públicos, os requerimentos de inscrição dos professores também eram publicados e assim podemos acompanhar o primeiro registro de requerimento de Pardal no periódico, em $1837,{ }^{10}$ para a cadeira de Inhaúma.

Figura 7 - Nota sobre requerimento de Pardal

\section{Dito ao Director das Fscolas de Primeiras Le-}

tras, enviando-lhe, para informar, o requerimento de Candido Matheus de Faria Pardal, em que pede ser admittido ao concurso da Cadeira de Primeiras Letras da Freguezia de Inhauma.

Fonte: Correio Oficial, 25 ago. 1837, n. 46, Biblioteca Nacional.

A checagem dos documentos parecia ocorrer com certo rigor, conforme sugere o encaminhamento feito ao diretor das escolas para que respondesse sobre a dúvida em torno da folha corrida apresentada pelo professor Pardal (Correio Oficial, 5 set. 1837). A "folha" consistia em um importante documento que visava assegurar a entrada de pessoas dentro dos preceitos de boa moralidade e conduta requeridos à função civilizadora que se esperava do magistério.

No período em que vigorava esse procedimento, entraram, no mesmo ano que Pardal, os professores José Maria Mafra, Joaquim Sabino Pinto Ribeiro, Francisco Antonio Augusto de Sá, Bernardino José de Sena, Estevão José Pires, e as professoras Francisca de Paula Moraes e Lima, Delfina Joaquina de Gouvea e Thereza Fortunata da Silva. Nos anos seguintes, o Reverendo João Soares de

${ }^{10}$ Correio Oficial, 25 ago. 1837, n. 46, Biblioteca Nacional. Este recorte é formado de duas partes que foram unidas no processo de edição da imagem, sendo a primeira frase da coluna direita da folha e a segunda, sua continuação na coluna esquerda. 
Lima e Mota, Manoel Joaquim da Silveira, João Antunes da Costa e Silva, e as professoras Clara Maria da Gloria Ribeiro e Catharina Lopes Coruja.

Alguns anos depois, em 1845, foi aprovado um decreto específico para regular os concursos públicos para professores. Composto por dezesseis artigos, o Decreto n. 440 de 10 de dezembro de 1845 definia o ritual a ser seguido durante as provas:

Começará o exame pela leitura; e o primeiro examinando, que o Diretor designar, indicando ao mesmo tempo o Professor, que o deve interrogar, aberto o respectivo escrutínio, extrairá uma cédula, e recitará em voz inteligível e pausadamente, o parágrafo do livro, que ela indicar, tendo o examinador na mão o outro exemplar. Acabada esta leitura, o examinador fará ao examinando as necessárias perguntas sobre a análise gramatical, sintaxe, regência, e concordância em um ou mais períodos. Este exame, assim como o das demais matérias, durará o tempo que o Ministro determinar.

Procedimento parecido era prescrito para as provas de aritmética, geometria (com uso de tábua preta), moral cristã e doutrina católica, escrita (também incluía o uso de papel) e, por fim, prática de ensino mútuo. Durante a vigência dessa norma, entraram no magistério público Joaquim José Cardoso de Siqueira Amazonas, Francisco Alves da Silva Castilho, João José Moreira, João Rodrigues da Fonseca Jordão, Antonio Gonçalves Teixeira e Souza, Ermelindo José Exposto, e as professoras Marianna Joaquina da Fonseca e Anna Euqueria Lopes Alvares. Vários desses professores se destacaram em suas atividades nas décadas seguintes, tornando-se conhecidos no ofício.

\section{“.. pede para instruir-se no sistema do Ensino Mútuo”}

No que diz respeito ao ensino mútuo, algumas questões como a formação, os concursos, o exercício em sala de aula no período em que esteve oficialmente em vigor na Corte e os seus resquícios, mesmo quando revogado, merecem ser destacados, na medida em que Pardal estava listado entre os que aplicavam o método e manteve, em parte, seu ensino após a Reforma de 1854.

O ensino mútuo foi estabelecido pela Lei de 1827. Baseava-se segundo Bastos (1999) no ensino dos alunos por eles mesmos, divididos em várias classes, sob a direção de um só mestre. Cada classe possuía um ritmo e um programa, 
dirigida por um monitor que recebia previamente instruções do professor. $\mathrm{O}$ método envolvia uma nova relação com materiais pedagógicos, mobília, tempo, espaço e agentes educativos. A sua exigência nos concursos públicos se deu antes mesmo do Decreto de 1845, anteriormente referido, que definia que: "Far-se-á por último o exame da prática do ensino-mútuo, do qual o examinando explicará um só processo, fazendo-o executar pelos meninos".

A cobrança de saber o sistema mútuo poderia ser inferida a partir de detalhes como do anúncio da imagem a seguir, embora não esteja explicitada no texto (Correio Oficial, 17 ago. 1836).

Figura 8 - Anúncio de abertura de concurso público em 1836

\section{ANNUNCIOS.}

\section{Pela Secretaria de Estado dos Negocios} do Imperio, se faz publico que no dia 13 do futuro mez de Setembro, se häo de pôr a concurso as Calleiras Publicas de Primeiras Letras para meninos, pertencenles is Freguezias de Guaratiba e Inhahuma, tendo cada huma dellas $150 \%$ rs. de ordenado. As pessoas que pretenderem os referidas Cadeiras, apresentar-se-hão. na Escola Publica de Primeiras Letras da Freguezia do Sacramento desta Cidade, no dia indicado, pelas 10 horas da manhã, a fim de serem examinadas; tendo primeiramente apresentado na dita Secretaria de Estado, os documentos que devem. labilita-las para o indicado Magisterio.

Rio de Janeiro em 13 de Ágosto de. 1836. - Luiz Joaquim dos Santos Marrocos.

Fonte: Correio Oficial, 17 ago.1836, n. 39, BN.

$\mathrm{O}$ aviso informa que o concurso para as cadeiras das freguesias de Guaratiba e Inhaúma seria realizado na Escola Pública de Primeiras Letras de Sacramento. O endereço de uma escola para realizar um exame de aprovação para o magistério público em pleno horário escolar chama atenção. Qual seria o motivo? Trata-se 
da escola regida pelo professor Francisco Joaquim Nogueira Neves, onde era oficialmente aplicado o ensino mútuo e também ensinado a outros professores.

Criada em 13 de abril de 1823, funcionava como escola normal pelo menos desde 1828, ano em que foi expedido um decreto, de 26 de novembro de 1828 , sobre aumento salarial do professor Francisco, o que corrobora a afirmação:

Decreto de 26 de Novembro de 1828

Eleva a $500 \$ 000$ o ordenado do Professor Publico da Escola Normal de ensino mútuo desta Corte.

Atendendo ao que Me representou Francisco Joaquim Nogueira Neves: Hei por bem que o ordenado anual de $400 \$ 000$, que percebe como Professor Público da Escola Normal de ensino mútuo da Corte, seja elevado á quantia de $500 \$ 000$ anuais, que lhe serão pagos pela respectiva folha do Tesouro Público. ${ }^{11}$

Notícias posteriores indicam seu funcionamento como Escola Normal até pelo menos 1839 , como as da autorização da reforma do prédio e conserto da mobília (Correio Oficial, 14 abr. 1835, n. 83), do pedido de gratificação feito pelo mesmo professor em 1836 (Correio Oficial, 1836, n. 111) e do pedido de admissão de um aspirante a professor público, no ano de 1839 (Correio Oficial, 9 set. 1939 , n. 58$)$.

Pelos documentos levantados, não foi possível apreender como se dava o funcionamento da Escola Normal de Ensino Mútuo. Contudo, considerando que ela estava instalada em uma escola de ensino primário, cujo professor era regente de uma cadeira de primeiras letras, parece que a instituição não funcionava nos moldes previstos para uma escola de formação docente. Porém, o fato de a ela ser atribuído o nome de "Escola Normal" não pode ser desconsiderado, pois indica a intencionalidade de formação, mais especificamente nesse caso, na aquisição dos conhecimentos necessários à aplicação do ensino mútuo. Nesse sentido, cabe destacar que a Lei de 1835, que criou a Escola Normal da Província, em Niterói, definia em seu segundo artigo que

A mesma Escola será regida por um Diretor, que ensinará. Primo: a ler e escrever pelo método Lancasteriano, cujos princípios teóricos e práticos explicará.

${ }^{11}$ Extraído da página da Câmara dos Deputados, disponível em http://www2.camara. leg.br. Acesso em março de 2014. 
Segundo: as quatro operações de Aritmética, quebrados, decimais e proporções. Tertio: noções gerais de Geometria teórica e prática. Quarto: Gramática de Língua Nacional. Quinto: elementos de Geografia. Sexto: os princípios de Moral Cristã, e da Religião do Estado.

$\mathrm{Na}$ Escola Normal de Niterói também haveria apenas um regente, com um currículo igualmente restrito - praticamente o mesmo preconizado pelo sexto artigo da Lei Geral de Ensino para ser ensinado nas escolas de primeiras letras -, sendo que o único ensino voltado para formação didática era o mesmo que ocorria na Escola Normal de Ensino Mútuo da freguesia de Sacramento, ou seja, o ensino mútuo. Cabe lembrar que Villela, ao tratar da fase inicial da instituição niteroiense, a ela se refere como uma "escola normal artesanal" (2002a).

Cardoso (1999), em estudo situado entre 1823 - ano em que o ensino mútuo foi implantado no Brasil -, e 1840, menciona uma Escola Normal de Ensino Mútuo criada por decreto de 1823, para instrução das corporações militares e extensiva a todas as classes, e extinta por decreto de junho de 1829. A autora assinala que

Como na Coleção de Leis do Império Brasileiro não encontramos nenhum outro decreto com a mesma data de $1^{\circ}$ de março de 1823, que criou a Escola Normal do ensino mútuo nesta Corte, podemos supor que a primeira escola organizada pelo novo método, para instrução principalmente do Exército, também formou novos professores, não no sentido formal que damos hoje à escola normal, mas funcionando como um centro difusor do conhecimento do método a ser repassado a outras pessoas interessadas em o aprender. E pelo texto do decreto de 20 de junho de 1829, tal iniciativa foi bem-sucedida, resultando na criação de novas escolas do mesmo tipo (1999, p. 122, grifo nosso).

O decreto que criou a Escola Normal da freguesia de Sacramento é outro, portanto tratar-se-iam de escolas distintas. E o próprio Decreto de 20 de junho de 1829 justifica a decisão de extinguir a escola criada em 01 de março de 1823 , alegando ser desnecessária "por se acharem cinco em exercício". Tal fato aponta a existência de outras unidades. Parece que uma das soluções encontradas para cumprir a Lei de 1827, que determinava que o professor que não tivesse instrução nesse ensino deveria fazê-lo em curto prazo e à custa dos seus ordenados, seria aprender com os "colegas professores" que o soubessem. 
A autora também menciona a escola de Sacramento onde lecionava Francisco Joaquim Nogueira Neves, criada para admitir até 270 meninos, mas como uma escola de primeiras letras que usava o ensino mútuo. Dirigida por uma junta diretora, tinha como professor "Francisco Joaquim Nogueira Neves, como endereço na Rua da Cadeia, que continuou ainda lecionando muitos anos, pois o encontramos atuante em 1835. Quanto à junta, foi extinta pelo decreto de 4 de março de 1829" (Cardoso, 1999, p. 123).

Apesar da extinção da referida junta, a escola continuou a funcionar como escola normal sob a regência desse professor, conforme indicam as fontes, até 1837, ano em que Francisco Neves pediu remoção para a cadeira da freguesia da Glória, onde lecionou até 1861, quando foi jubilado. Em 1837, foi substituído por Joaquim Sabino Pinto Ribeiro, que também não encerrou a atividade da Escola Normal, pois foi possível localizar um anúncio de que o Ministro do Império havia visitado a Escola Normal de Ensino Mútuo da freguesia de Sacramento, sob sua regência, em 10 de outubro de 1837 (Correio Oficial, 16 out. 1837).

Outras escolas de primeiras letras em que o sistema de ensino mútuo era usado foram apresentadas por Cardoso em um quadro composto por quinze professores que atuaram com o método entre 1823 e 1840 . O próprio professor Pardal se encontra em uma listagem de professores públicos de 1839 que usavam o método mútuo (AGCRJ, códice 10.4.4, 26 abr. 1839, f.3).

Anos depois, em 1849, Pardal recebeu uma quantia para as despesas com a montagem da escola pública de Santa Rita "pelo sistema de ensino mútuo", informação que poderia ter relação com o fato de que a escola havia mudado para outro endereço. Nesse caso, talvez fosse preciso trocar, reparar ou aumentar a mobília, ou significasse que, no prédio anterior, a escola funcionava sem a mobília preconizada para o sistema. No entanto, era comum que escolas que afirmavam empregar o ensino mútuo, na prática, apenas se ativessem ao uso de termos e expressões relativos ao método, bem como de mobília e materiais, mas não a aplicação do método em si. $^{12}$

Cabe destacar que, mesmo após a instituição na Corte do ensino simultâneo pelo Regulamento de 1854, o sistema mútuo ou alguns de seus elementos persistiam nas práticas escolares, sinal de que a apropriação do método ou de parte de seus dispositivos - provavelmente uma apropriação criativa, diante das

${ }^{12}$ Reflexão sugerida por Anne-Marie Chartier em reunião de pesquisa durante o doutorado-sanduíche. 
circunstâncias da realidade brasileira -, poderia ter adquirido um caráter de tradição difícil de extirpar. Um dos mapas de matrícula do ano de 1855 do professor Pardal, usado nesta pesquisa para fazer uma análise dos pais e encarregados dos alunos, registra que o professor usava o método "misto, de mútuo e simultâneo", aspecto que poderia se refletir na mobília da escola de forma muito peculiar.

Quase vinte anos depois, em relatório da Comissão Visitadora das Escolas da Corte de 1873, na parte a respeito do assunto, a comissão aconselha que a mobília da escola de Santa Rita fosse completamente "reformada". A comissão descreve a escola como tendo duas salas, sendo a da frente do sistema número 2 e a do interior, de número 1 e que ainda assim eram insuficientes para a frequência ordinária. As carteiras chamadas do "sistema 1" eram descritas deste modo:

Mesa de pinho pintado de preto, com pequena inclinação, tendo 3,20m de comprimento, $0,4 \mathrm{~m}$ de largura e $0,76 \mathrm{~m}$ de altura. $\mathrm{O}$ respectivo banco, sem encosto, mede $0,43 \mathrm{~m}$ de altura, e 0,20 de largura, e é fixo à mesa. Esta tem por baixo do tampo pequenos repartimentos para os alunos guardarem livros, cadernos, etc. Uma travessa de madeira, presa à mesa em todo o comprimento desta, serve para apoio dos pés; perpendicular à mesa existem 6 ou 7 hastes de ferro donde pendem os quadros de escrita (p. 24).

A mobília sugere o ensino ao qual se prestava e o relatório fornece uma observação histórica a respeito delas: "Esta mobília foi introduzida em $1828 \mathrm{ou}$ 1829 e serviu para as primeiras escolas de ensino mútuo. Ainda existem alguns raros e venerandos espécimes desse gênero nas escolas de meninos do curato de Santa Cruz, de Inhaúma e $1^{\text {a }}$ de Santa Rita" (p. 25).

A mistura entre carteiras antigas e mais modernas em uma mesma escola consiste numa realidade que vai se propagar ao longo do tempo a despeito da presença mais incisiva dos discursos higienistas, das propagandas em torno da modernidade pedagógica, da constituição de uma "indústria escolar", bem como de questões econômicas que iriam emergir no final do século XIX no Brasil, como assinala Alcântara (2014). Cabe destacar que a renovação de mobília e de materiais pedagógicos tanto era bem recebida como requisitada pelos docentes.

Em 1873, portanto, uma das possibilidades de ocorrer o "método misto" seria de aplicar separadamente o método mútuo e o simultâneo, cada um numa sala, em uma mesma escola, como parecia funcionar na Escola de Santa Rita, beneficiada pela divisão de salas, ou prejudicada por ela. No entanto, o endereço 
da escola informado pelo relatório, Rua do Príncipe, n. ${ }^{\circ}$ 80, era recente. Era do mesmo ano da visita, conforme registra o Almanak Laemmert. Desse modo, não sabemos se o mesmo procedimento teria sido adotado por Pardal nos outros prédios ocupados.

Esse exemplo serve de ilustração ao comentário da comissão sobre os métodos seguidos nas escolas públicas da Corte. Ao defender que ensino misto era o que melhor que se prestava às condições existentes, afirma que "não pareceu à comissão que ele fosse executado sempre com toda perfeição, nem tão pouco o simultâneo, o que não é aliás de estranhar da parte do nosso pessoal docente, que, não possuindo, em geral, estudos regulares, aplica esses métodos como cada qual entende" (p. 53). A afirmação um tanto jocosa a respeito do uso dos métodos, atribuído à falta de estudos regulares, provavelmente não se direcionava ao professor Pardal que tinha reconhecimento dos colegas em termos de saber pedagógico. No entanto, não foi possível saber se Pardal teve uma formação institucional para aprendizagem do sistema mútuo, mas havia essa possibilidade, como, por exemplo, nas escolas normais de ensino mútuo.

Em meio às discussões sobre o ensino mútuo, a abertura de escolas normais no país, ao ordenamento jurídico que se impunha à instrução, um outro acontecimento iria afetar o modo pelo qual a autoridade máxima do país era registrada nos documentos oficiais, entre os quais aqueles produzidos pelo funcionamento da instrução: a maioridade de D. Pedro II em 1840. Os professores não ficaram indiferentes ao fato. $\mathrm{O}$ diretor das escolas, Joaquim Silveira, enviou uma carta de felicitação ao Imperador, acompanhada das assinaturas de mais quatro professores públicos de primeiras letras, sendo um dos signatários o professor Pardal.

A carta felicitava D. Pedro II pelo acontecimento. A missiva laudatória, como preconizavam as regras de bom-tom, ao mesmo tempo em que pedia proteção às escolas, procurava passar uma mensagem do papel que o Imperador não deveria esquecer no alto de "sua ilustração" no que dizia respeito à importância do ensino primário (Correio oficial, 24 out. 1840). A resposta de D. Pedro II às felicitações foi bastante formal e padronizada assim como a dos outros felicitantes: "S.M.I. Respondeu que agradecia muito os sentimentos que Lhe manifestavam os Srs. Diretor, e Professores públicos de Primeiras Letras do Município da Corte”.

O diretor das escolas havia estado em presença do Imperador para entregar a carta e "estar em presença" e cumprimentar o governante da nação foi uma prática comum entre os professores públicos primários (ver apêndice 10). Vários deles tiveram a "honra", como diziam os jornais, de fazê-lo, como o próprio pro- 
fessor Pardal que, em 1853, participava de uma comissão da Imperial Sociedade Amante da Instrução que apresentou ao Imperador o pedido de aquisição de um terreno para construção de um colégio para meninas órfãs e meninos indigentes (Correio Mercantil, 06 abr. 1853). Talvez a visita fosse um procedimento bem visto e poderia corroborar para construir uma "boa imagem", aspecto que parecia também fazer parte da docência, quando o sujeito que se revestia da função procurava exercer atividades que extrapolassem o espaço escolar, embora conectadas, como, por exemplo, a política.

\section{“... ficam revogadas as disposições em contrário”}

Mesmo com as dificuldades encontradas pelo governo para ajustar a fiscalização das escolas e outros aspectos da instrução pública, o movimento jurídico das primeiras décadas após a independência ajuda a compreender a constituição das legislações que se seguiram e que são bastante conhecidas da historiografia, como o Regulamento de 1854 e o de 1879.

Como é sabido, após o Regulamento das Escolas de Primeiras Letras da Província do Espírito Santo, de 1848, e o Regulamento da Instrução Primária na Província do Rio de Janeiro, de 1849, o Ministro do Império Luiz Pedreira do Couto Ferraz deu prosseguimento à sua ação reformadora estabelecendo o Regulamento da Instrução Primária e Secundária da Corte, em 1854. Ele reuniu em um único código jurídico a normatização de aspectos da instrução que tinham regras dispersas, bem como regulou "normas" instituídas pela tradição que não possuíam algo "em contrário" com as disposições "novas" da reforma. Dessa forma, o Regulamento tratou, em cinco títulos, da inspeção, do magistério (formação, recrutamento, deveres e direitos), funcionamento das escolas e dos processos disciplinares. Segundo Schueler (2002, p. 250):

A lei, então, estabeleceu uma série de obrigações e deveres aos professores, e, em contrapartida, como toda relação jurídica, conferia-lhes direitos e privilégios. $\mathrm{O}$ que, em certa medida, para os historiadores da profissão docente, explicaria a vitória, ainda que contestada e turbulenta, do processo de estatização e a conseqüente incorporação dos mestres ao corpo de funcionários públicos - portanto, sua adesão, em maior ou menor nível, ao controle estatal. 
Entretanto, Schueler igualmente defende que, apesar do Regulamento pretender controlar a atividade docente, havia espaço para autonomia dos mestres, pois, apesar submetidos à ingerência estatal, os professores "dispunham de mecanismos institucionais através dos quais poderiam viabilizar o diálogo e a comunicação com o poder público" (2002, p. 181). O interesse em estabelecer diálogo com a administração poderia ter motivado a reunião entre professores primários e secundários no Imperial Colégio de D. Pedro II noticiada em $O$ Correio da Tarde (5 jun. 1857). Pardal, professor primário e do Colégio, fez parte da comissão criada na reunião para apresentar as bases para o estatuto de uma associação de professores, com o fim de melhorar o ensino primário e secundário. Nesse sentido, de acordo com Lemos (2006), diante de um Estado que se organizava, os professores também começaram a se organizar.

A Reforma de 1854, segundo Gondra (2001), estabelecida no Gabinete da Conciliação (1853-1856) emergiu em meio de conflitos em torno de posições e projetos observados no próprio núcleo do poder responsável pela sua execução. Com o fim da "Conciliação", os nervos poderiam estar mais exaltados, refletindo-se nos discursos de Eusébio na inspetoria e nas reuniões de professores para organizar uma associação.

Discussões sobre a Reforma de 1854 podem ser vistas em Villela (2002), Schueler (2002), Gondra (2001), Neves (2006), Borges (2008), entre outros vários autores. De uma forma geral, a reforma regulou práticas já existentes como a "forma artesanal de reprodução da docência" (Villela, 2002a e Schueler, 2002) - que podem ser analisadas a partir do conceito de "tradição inventada" - e também instituiu mudanças. $\mathrm{O}$ antigo esquema de fiscalização exercido por diretor e fiscais da Câmara foi substituído por um mais sofisticado, ao menos na letra da lei, centralizado na Inspetoria Geral de Instrução Primária e Secundária. O ensino mútuo foi substituído pelo ensino simultâneo. Regulou-se a formação pela prática, por meio da criação dos professores adjuntos que acabaram por assumir o papel do professor substituto. Para o recrutamento de professores mantiveram-se os concursos públicos, cujos procedimentos funcionavam como formação docente (Garcia, 2005). Criou-se a escola primária graduada em $1 .^{\circ}$ e $2 .^{\circ}$ graus.

Desde a entrada de Pardal em 1837 até o ano de 1853, passaram pelas cadeiras de primeiras letras cerca de 32 professores. Entre eles, seis professoras e quinze professores iriam ter a experiência de trabalhar sob o Regulamento de Couto Ferraz. 
Quadro 2 - Professores e professoras em exercício em 1854 nomeados antes da Reforma

\begin{tabular}{|c|c|c|c|}
\hline N. & Professor & Ano de nomeação & Final do exercício \\
\hline 1 & José de Moraes & 1834 & Falecido em 28/10/1859 \\
\hline 2 & Francisco Joaquim Nogueira Neves & $\begin{array}{c}1834 \\
1837 \text { (relatório) }\end{array}$ & Jubilado em $5 / 10 / 1861$ \\
\hline 3 & Anna Joaquina de Oliveira e Silva & 1835 & Falecida em 20/08/1861 \\
\hline 4 & Venancio José da Costa & $\begin{array}{l}1835 \\
1837\end{array}$ & Jubilado em 05/12/1856 \\
\hline 5 & Luis José de Mello & $1835 ?$ & $\begin{array}{l}\text { Morte em } 1855 \text { (Correio Mercan- } \\
\text { til, } 9 / 02 / 1855)\end{array}$ \\
\hline 6 & Francisca de Paula Moraes e Lima & 1837 & Jubilada em 15/04/1871 \\
\hline 7 & Thereza Fortunata da Silva & 1837 & Jubilada em 28/12/1863 \\
\hline 8 & Joaquim Sabino Pinto Ribeiro & 1837 & Jubilado em 28/03/1863 \\
\hline 9 & Francisco Antonio Augusto de Sá & 1837 & Falecido em 28/11/1866 \\
\hline 10 & Candido Matheus de Faria Pardal & 1837 & Jubilado em 8/7/1874 \\
\hline 11 & Estevão José Pires & 1837 & Falecido em 1/07/1863 \\
\hline 12 & Clara Maria da Gloria Ribeiro & 1841 & Jubilada em 1868 \\
\hline 13 & Manoel Joaquim da Silveira & 1842 & Jubilado em 8/10/1864 \\
\hline 14 & João Antunes da Costa e Silva & 1842 & Falecido em 06/03/1863 \\
\hline 15 & Catharina Lopes Coruja & 1843 & Jubilada em 17/01/1874 \\
\hline 16 & $\begin{array}{l}\text { Joaquim José Cardoso de Siqueira } \\
\text { Amazonas }\end{array}$ & 1848 & Falecido em 26/04/1866 \\
\hline 17 & Francisco Alves da Silva Castilho & 1849 & Jubilado em 12/02/1887 \\
\hline 18 & João José Moreira & 1849 & Falecido em 16/08/1873 \\
\hline 19 & João Rodrigues da Fonseca Jordão & 1849 & Jubilado em 14/02/1879 \\
\hline 20 & Ermelindo José Exposto & 1852 & Falecido em 1855 \\
\hline 21 & Anna Euqueria Lopes Alvares & 1853 & $\begin{array}{l}\text { Última notícia em Relatório } \\
\text { da IGIPSC de 30/11/1876 } \\
\text { (gratificação) }\end{array}$ \\
\hline
\end{tabular}

Fonte: Quadro elaborado pela autora com base nos relatórios da IGIPSC, documentos manuscritos do AGCRJ, no Correio Oficial - folha do governo, referente ao período anterior a 1854, e no Almanak Laemmert.

Como a maior parte deles estava em exercício desde a década de 1830, alguns saíram nos primeiros anos da Reforma por morte ou jubilação. Aqueles 
que continuaram atuando puderam acompanhar um processo de mudanças, mas também de permanências que persistiram anos após a Reforma. Para esses professores que já estavam em exercício, o Regulamento de 1854 havia determinado que

Art. 25. Os atuais professores continuarão a vencer os mesmos ordenados que ora percebem.

Os que forem providos de novo, e os que se habilitarem na forma deste Regulamento, no prazo que lhes será marcado, terão os seguintes vencimentos, a saber: Os professores das escolas de segundo grau, 1.000\$000 de ordenado e 400\$000 de gratificação.

Os das escolas de primeiro grau, $800 \$ 000$ de ordenado e $200 \$ 000$ de gratificação.

Ou seja, precisavam se habilitar "na forma do regulamento" para receberem os novos vencimentos. Em 1855, um ano após a Reforma, o professor Pardal solicitou se submeter aos procedimentos de habilitação, acionando sua rede de relações (AGCRJ, códice 10.4.31, 20/03/1855, f. 20). No AGCRJ, encontram-se cinco atestados de moralidade do professor, documento exigido para o pleito (AGCRJ, códice 10.4.31, f. 25-26, 28, 30 e 32.). Os atestados permitem ver os tipos de sujeitos que Pardal acionou para comprovar sua moralidade. Ele mobilizou um vigário, dois militares, um médico e um engenheiro. Interessante é perceber em cada atestado as evidências das relações e o seu caráter.

O Vigário Manoel da Silva Lopes da Igreja Matriz de Santa Rita assevera no atestado que Pardal cumpria bem seus deveres havia mais de quatro anos: "sua conduta tanto civil quanto religiosa tem sido exemplar e se faz digno de todos os respeitos". O envolvimento de Pardal com instituições de caráter religioso se deu de maneira ativa, por meio da ocupação de cargos de direção, como veremos no capítulo III. Um dos militares, Luis Antonio da Silva Beltrão, registrou todas as suas comendas para legitimar suas declarações acerca de Pardal, a quem conhecia há mais de 20 anos, ou seja, antes mesmo de ser professor público. Essa convivência poderia se dar na Sociedade Auxiliadora da Indústria Nacional, da qual ambos eram sócios. No ano seguinte, em 1856 seria possível encontrar um filho de Beltrão no mapa de matrícula de Pardal. O outro militar, Feliciano José Neves Gonzaga, também enumerou suas comendas e declarou conhecer o professor há 16 anos. Como prova testemunhal, relatou que "sob sua direção foi doutrinado um filho meu, que atualmente faz o seu curso de medicina”. O médico que também fez um atestado de moralidade foi Antonio Félix Martins, presidente da 
Junta Central de Higiene Pública, que viria ser membro do Conselho Diretor da Instrução (1861-1864), inspetor geral da instrução (interino, 1860, 1861 e 1864, e efetivo em 1873), vereador e membro do conselho da majestade.

No caso dos professores que entraram por meio dos concursos públicos realizados a partir da vigência do Regulamento de 1854 até o ano de 1870, estão:

Quadro 3 - Professores nomeados entre 1854 e 1870. Os nomes em itálico indicam os que haviam sido adjuntos.

\begin{tabular}{|c|l|c|l|}
\hline N. & Professor & Ano de nomeação & Final do exercício \\
\hline 1 & Joaquim Fernandes da Silva & 1855 & Jubilado em 14/01/1888 \\
\hline 2 & Luiz Thomaz de Oliveira & 1855 & Falecido em 03/08/1864 \\
\hline 3 & João Ferreira Moscoso & 1855 & Jubilado em 15/04/1871 \\
\hline 4 & Polycarpo José Dias da Cruz & 1855 & Exonerado em 18/03/1858 \\
\hline 5 & José Theodoro Burlamaque & 1856 & - \\
\hline 6 & Marcos Bernardino da Costa Passos & 1856 & Falecido em 31/08/1865 \\
\hline 7 & Antonio Joaquim de Miranda & $1857 / 1865$ & Falecido em 29/10/1866 \\
\hline 8 & Joaquim José de Souza Ribeiro & 1857 & Jubilado em 30/09/1884 \\
\hline 9 & $\begin{array}{l}\text { Antonio Pinto da Costa de Souza } \\
\text { Brandão }\end{array}$ & 1858 & Falecido em 1868 \\
\hline 10 & Antonio Ignácio de Mesquita & 1858 & Falecido em 18/07/1873 \\
\hline 11 & José Bernardes Moreira & 1858 & Jubilado em 14/01/1888 \\
\hline 12 & João Marciano de Carvalho & 1858 & Jubilado em 10/02/1884 \\
\hline 13 & João da Matta Araujo & $1858 / 1863$ & Jubilado em 19/06/1886 \\
\hline 14 & $\begin{array}{l}\text { Antonio Cypriano de Figueiredo } \\
\text { Carvalho }\end{array}$ & $1859 / 1863$ & Jubilado em 13/03/1886 \\
\hline 15 & Joaquim Antonio da Silva Bastos & 1860 & Jubilado em 1897 \\
\hline 16 & José Joaquim Xavier & 1861 & Jubilado em 19/07/1884 \\
\hline 17 & Manoel José Pereira Frazão & - \\
\hline 18 & Gustavo José Alberto & Joano Pedro de Medina Coeli Mariz & - \\
\hline 19 & Sarmento & Falecido em 17/10/1866 \\
\hline 20 & Olympio Catão Viriato Montez & Jubilado em 30/09/1890 \\
\hline 21 & Antonio Candido Rodrigues Carneiro & 1865 & - \\
\hline
\end{tabular}




\begin{tabular}{|c|l|c|l|}
\hline 22 & João Gonçalves Paim & 1865 & - \\
\hline 23 & João Pedro dos Santos Cruz & 1866 & - \\
\hline 24 & Antonio Estevão da Costa e Cunha & 1867 & Jubilado em 30/09/1890 \\
\hline 25 & José Antonio de Campos Lima & 1867 & Jubilado em 18/05/1886 \\
\hline 26 & João Correa dos Santos & 1867 & Falecido em 30/06/1883 \\
\hline 27 & José Joaquim Pereira de Azurara & 1867 & Demitido em 02/07/1872 \\
\hline 28 & Armando de Araújo Cintra Vidal & 1867 & - \\
\hline 29 & Francisco Fernandes Machado & 1868 & - \\
\hline
\end{tabular}

Fonte: Quadro elaborado pela autora com base nos relatórios da IGIPSC, documentos manuscritos do AGCRJ e no Almanak Laemmert.

Quadro 4 - Professoras nomeadas entre 1854 e 1870. Os nomes em itálico indicam as que haviam sido adjuntas

\begin{tabular}{|c|l|c|l|}
\hline N. & Professora & Ano de nomeação & Final do exercício \\
\hline 1 & Umbelina Maria da Cruz e Almeida & $1854(\mathrm{AL})$ & - \\
\hline 2 & Francisca Albina Ferreira & 1855 & Jubilada em 27/07/1866 \\
\hline 3 & Elisa Tanner & 1855 & Jubilada em 14/01/1888 \\
\hline 4 & Eulália Emilia Nervi & 1855 & Pediu demissão em 1856 ou 1857 \\
\hline 5 & Maria Thomazia de Oliveira e Silva & 1855 & - \\
\hline 6 & $\begin{array}{l}\text { Amália Justa dos Passos Coelho } \\
\text { Amália Justa dos Passos Coelho e }\end{array}$ & 1855 & Jubilada em 15/12/1890 \\
\hline 7 & Anna Joaquina da Costa Passos & 1856 & Falecida em 12/01/1869 \\
\hline 8 & Joanna Amalia de Andrade & 1857 & - \\
\hline 9 & $\begin{array}{l}\text { Luiza Candida de Mendonça } \\
\text { Cardoso }\end{array}$ & 1858 & - \\
\hline 10 & Delphina Rosa da Silva Vasconcellos & 1858 & Jubilada em 23/03/1884 \\
\hline 11 & $\begin{array}{l}\text { Maria Antonia da Luz Franco ou, em } \\
\text { 1859, Maria Antonia Martins Franco } \\
\text { (1859) }\end{array}$ & 1858 & Demitida em 1860 \\
\hline 12 & Theresa de Jesus Araujo Sampaio & 1858 & Pediu demissão em 1858 \\
\hline 13 & Luiza Ferreira Sampaio & 1858 & - \\
\hline 14 & Angelica de Athayde Jordão & $1859 / 1862$ & - \\
\hline 15 & $\begin{array}{l}\text { Deolinda Maria da Cruz e Almeida } \\
\text { Araujo }\end{array}$ & 1861 & Jubilada em 14/01/1888 \\
\hline
\end{tabular}




\begin{tabular}{|c|l|c|l|}
\hline 16 & $\begin{array}{l}\text { Maria da Gloria de Almeida Feijó } \\
\text { Maria da Gloria Lacé de Alvarenga } \\
(1871)\end{array}$ & 1862 & Jubilada em 26/10/1878 \\
\hline 17 & Alcida Brandelina da Costa Seixas & 1863 & Exonerada em 20/09/1870 \\
\hline 18 & Maria José dos Santos Lara & 1864 & Jubilada em 23/09/1890 \\
\hline 19 & $\begin{array}{l}\text { Mathilde Carolina da Silveira } \\
\text { Mathilde Carolina Ferreira (1866) }\end{array}$ & 1865 & Exonerada em 1875 \\
\hline 20 & Flavia Domitilla de Carvalho & 1866 & - \\
\hline 21 & $\begin{array}{l}\text { Thereza Leopoldina de Araújo } \\
\text { Thereza Leopoldina de Araújo } \\
\text { Jacobina (1881) }\end{array}$ & 1869 & Falecida em 31/03/1884 \\
\hline 22 & Maria Leopoldina Ferreira & 1870 & - \\
\hline 23 & $\begin{array}{l}\text { Anna Alexandrina de Vasconcellos } \\
\text { Medina }\end{array}$ & 1870 & - \\
\hline 24 & Maria Nazareth dos Santos Garrocho & 1870 & Falecida em 06/08/1873 \\
\hline
\end{tabular}

Fonte: Quadro elaborado pela autora com base nos relatórios da IGIPSC, documentos manuscritos do AGCRJ e no Almanak Laemmert.

Os dois quadros apresentam, com destaque em itálico, a indicação daqueles que compuseram a chamada "classe dos professores adjuntos", política de formação docente adotada pelo governo. Um total de vinte professores e professoras "formados pela prática" estão sinalizados nos quadros, número que iria aumentar na década seguinte, sinal de que a adesão à regulamentação da função foi bastante significativa. Marcos Bernardino da Costa Passos foi enquadrado na função de adjunto como uma solução burocrática para o posto que ocupava e que não era mais previsto explicitamente no Regulamento de 1854, o de professor substituto: "Art. 44. Os atuais substitutos das escolas serão conservados e empregados como adjuntos, enquanto se lhes não der outro destino”.

No entanto, o fato de terem sido adjuntos dentro das normas do Regulamento de 1854, registrados nos relatórios da Inspetoria, não significa que os outros não pudessem ter aprendido a profissão da mesma forma, em razão de possuírem relações de parentesco ou de amizade com o professor-regente. No entanto, não constavam oficialmente nos quadros da Inspetoria.

Diante de um paradigma que preconiza a formação docente no interior de um modelo institucional específico, afirma-se que o estabelecimento da chamada "formação pela prática" se deu em detrimento da formação pela escola normal. E diante de um paradigma das "corporações de ofício", afirma-se que a classe dos adjuntos consolidava práticas tradicionais de aprendizagem do ofício e de 
transmissão familiar, pois filhos e parentes de professores poderiam tornar-se adjuntos e perpetuar a "tradição", agora de forma oficial e submetida ao controle estatal (Schueler, 2002). Schueler, desse modo, assinala que se pode afirmar que a escola primária oitocentista "ensina por si mesma".

Embora a medida representasse a institucionalização de uma prática recorrente, não significa que problemas não tivessem ocorrido no seu funcionamento, como aqueles inerentes às peculiaridades do ensino, das tradições e práticas sociais e culturais da época. Sobretudo da ordem do privado, que havia corroborado para a própria recorrência da formação artesanal. A casa, que na maioria das vezes também era a escola, foi palco de muitas relações conflituosas entre os próprios professores, suas respectivas famílias e o governo, apresentando um emaranhado de relações em que o público e o privado se confundiam, frequentemente de maneira tensa e heterogênea. A casa, desse modo, servia como importante lugar da constituição da profissão e de suas relações, principalmente no aspecto da transmissão tradicional do ofício (Schueler, 2002).

$\mathrm{O}$ artigo 35 do Regulamento de 1854 concedia privilégio aos filhos de professores, mas não havia restrições àqueles que não eram parentes para assumirem o cargo. Assim, estranhos poderiam tornar-se adjuntos da escola em que um professor lecionava e na qual, com sua família, morava, gerando alguns conflitos. Sobretudo no caso das escolas de meninas, onde também se produzia o fardo moral que cercava as mulheres. A entrada de uma estranha no ambiente dominado e organizado por uma família desestabilizava a instituição e ameaçava a tradição. Um membro da família poderia perder o lugar "socialmente cativo" para uma "forasteira". Schueler (2002, p. 183, grifo nosso) assinala que

Em outros casos, as autoridades argumentavam que algumas delas, julgando-se proprietárias das cadeiras de ensino, recusavam-se a receber meninas que não estivessem inscritas em suas relaçôes pessoais de parentesco ou amizade, para servir como auxiliares. Estes relatos, sem dúvida, indicam e evidenciam a complexidade e as tensões entre o público e o privado, que imprimiam novas direções e marcavam especificidades ao processo de construção do sistema público de ensino primário na Corte.

Nesse sentido, podemos compreender o pedido de José Vicente Jorge, delegado da instrução, para que o inspetor geral tomasse providências diante 
da reação turbulenta da professora da freguesia de Santo Antônio, Amália Justa dos Passos Coelho:

Estornada (?) pela exoneração de sua irmã Francisca Augusta dos Passos Coelho, que exercia interinamente o lugar de adjunta de $1^{\circ}$ ano na mesma escola havia seis anos, sem nunca apresentar-se nos exames anuais, para as quais era sempre intimada, não só recusou com desabrimento receber a snr D. Josepha Thomazia Gomes [...] como tomou por si a resolução de despedir com maus modos a adjunta D. Flávia Domitilla de Carvalho que já lá servia [...] (AGCRJ, códice 11.2.9, 11jul. 1864, f. 192).

O inverso também deve ser considerado. A família de uma adjunta também não queria que ela fosse coadjuvar uma estranha. O inspetor Eusébio de Queiroz atribuía o conflito à própria educação feminina: "devo declarar a V. Ex., que os hábitos, a educação e os costumes que infelizmente dominam ainda entre nós, tem suscitado embaraços e dificuldades no devido desenvolvimento da classe das professoras adjuntas" (Relatório da IGIPSC, 1856, p. 5). Um determinado ideário de educação feminina voltado para a vida doméstica, preconizada também pelas próprias autoridades, "mesmo não correspondendo a experiência de vida de grande parte das mulheres” (Gouvea, 2003, p. 7) estava interferindo nos planos e políticas voltados para a instrução pública.

O problema continuou sendo registrado nos relatórios posteriores, evidenciando que a força da tradição parecia não se abalar. Segundo o inspetor, eles continuavam lutando contra os costumes e hábitos, "apesar da diligência empregada” - provavelmente referindo-se ao aumento dos vencimentos:

Assim persistem em não deixar o domicílio de suas famílias para substituírem ou auxiliarem as professoras das escolas que exigem seus serviços, ao mesmo tempo que estas se recusam a recebê-las em suas casas, quando não existem de parte a parte relações de íntima amizade ou parentesco (Relatório da IGIPSC, 1860, p. 6).

Embora as professoras públicas e as adjuntas fossem burocraticamente "subalternas", podemos observar a agência de tais mulheres que, a despeito de uma suposta inferioridade em termos de poder, detinham uma autoridade tal, corroborada pelas tradições, que obrigava o governo a negociar o modo como se dava o exercício do cargo de adjunto nas escolas do sexo feminino. 
Apesar dos diversos problemas, torna-se importante não negligenciar certos aspectos da formação pela prática que podem ficar obliterados pelos debates em prol da Escola Normal e que se tornam mais evidentes quando comparamos os professores dos quadros de nomeação a partir de 1854 ( 3 e 4) com os do quadro 2, de professores nomeados antes da Reforma de 1854.

Quadro 5 - Ex-adjuntos X professores-regentes

\begin{tabular}{|c|c|c|}
\hline \multicolumn{2}{|c|}{ Professor ex-adjunto e ano de sua nomeação } & Nome do professor-regente \\
\hline Marcos Bernardino da Costa Passos & 1855 & \multirow{2}{*}{ Candido Matheus de Faria Pardal } \\
\hline José Antonio de Campos Lima & 1860 & \\
\hline Antonio Joaquim de Miranda & 1855 & João José Moreira \\
\hline Antonio Ignácio de Mesquita & 1856 & \multirow{2}{*}{ Francisco Antonio Augusto de Sá } \\
\hline José Joaquim Xavier & 1856 & \\
\hline Olympio Catão Viriato Montez & 1863 & ? \\
\hline João Gonçalves Paim & 1859 & $\begin{array}{l}\text { Joaquim José Cardoso de Siqueira Ama- } \\
\text { zonas }\end{array}$ \\
\hline João Correa dos Santos & $\begin{array}{l}1860 \\
1861\end{array}$ & $\begin{array}{l}\text { João José Moreira } \\
\text { Polycarpo José Dias da Cruz }\end{array}$ \\
\hline Armando de Araújo Cintra Vidal & 1861 & $\begin{array}{l}\text { João Antunes da Costa e Silva } \\
\text { José Joaquim Xavier }\end{array}$ \\
\hline Francisco Fernandes Machado & 1867 & João Rodrigues da Fonseca Jordão \\
\hline
\end{tabular}

Fonte: Quadro elaborado pela autora com base nos relatórios da IGIPSC, documentos manuscritos do AGCRJ e no Almanak Laemmert.

Um mesmo professor poderia ser coadjuvado por mais de um adjunto, o que permitiria estabelecer mais relações, indicar mais alunos ou inserir mais parentes. ${ }^{13}$ No caso do quadro 5, o grupo de professores das escolas em que os adjuntos listados atuaram eram aqueles que, em sua maior parte, estiveram envolvidos em atividades associativistas e em sociedades - como, por exemplo, na organização da Academia Pedagógica, em 1860 -, em debates pedagógicos, participando como examinador de bancas de concursos públicos, de habilitação, de conclusão de primeiras letras, entre outros, configurando uma "agência docente".

${ }^{13} \mathrm{O}$ Decreto n. ${ }^{\circ} 1.681$, de 28 de novembro de 1855 , determinou a presença de um adjunto para cada escola com frequência "efetiva e real por mais de um ano" de mais de 50 alunos; dois as que contarem mais de cem; três as que tiverem mais de 150; "havendo mais três além dos que forem necessários nesta proporçáo". 
Fonseca Jordão, por exemplo, foi membro da comissão nomeada para melhorar o plano e o programa do exame dos adjuntos do $3 .^{\circ}$ ano (Relatório da IGIPSC, 1872), mostrando uma agência formativa por parte dos professores regentes que participavam de mais de uma etapa na formação dos adjuntos, fosse na sala de aula, na definição de saberes que dariam a habilitação final aos candidatos à docência e no próprio exame, de cuja banca examinadora faziam parte professores de primeiras letras. Também funcionava com um modo de selecionar aqueles que seriam os seus futuros colegas de trabalho, principalmente nos casos em que não havia ligação de parentesco. Ligação essa em que o controle sobre a formação tende a ser maior pela proximidade e pelos constrangimentos que a relação familiar poderia impor.

Pardal esteve em diversas bancas de exame de adjuntos, muitos dos quais se encontram quadros 3 e 4: João Gonçalves Paim, José Antonio de Campos Lima, João Correa dos Santos, Armando de Araújo Cintra Vidal, Mathilde Carolina da Silveira, Mathilde Carolina Ferreira, Flavia Domitilla de Carvalho, Thereza Leopoldina de Araújo e Maria Nazareth dos Santos Garrocho (AGCRJ, códice 11.2.10, fs. 71-212). Nem todos receberam boa avaliação de Pardal e de João José Moreira, outro membro da banca, como no caso do adjunto João Correa dos Santos, que "esteve sofrível em português e história sagrada, e fraco em aritmética e pesos e medidas" (f.148).

Nesse sentido, chama atenção o fato de que no grupo de professores regentes vários eram conhecidos por terem um destacado conhecimento de questões pedagógicas - alguns analisados por Schueler como parte de um grupo de intelectuais (2008a e 2008c). Tal fato, de certo modo, poderia conferir à chamada "formação pela prática" um pouco mais de saberes pedagógicos do que se costuma supor. Desse modo, a teoria tão preconizada na formação científica dos professores e que era atribuída ao ensino pela Escola Normal como único espaço possível de aprendizagem desse saber, também poderia, de certo modo, fazer parte da formação do adjunto, dependendo do professor regente que o acolhesse. Tal hipótese não desconsidera a importância dos debates em favor das escolas normais, dos quais tais professores também estiveram envolvidos, mas visa redimensionar a formação dos adjuntos frente a uma perspectiva fortemente pragmática conferida a ela.

Conhecimentos que poderiam ser aprimorados numa sociedade como a Academia Pedagógica. Instalada em 1860 com a participação do professor Pardal, tinha "o fim de estudar a pedagogia e todas as matérias relativas ao ensino 
primário" (Correio Mercantil e O Correio da Tarde, 26 jul. 1860). A Academia constituiu um espaço de formação pedagógica, tanto teórica quanto prática, agenciada pelos próprios professores. A iniciativa autônoma denota um investimento em saberes pedagógicos que, embora não fossem aprendidos dentro das formalidades de uma escola normal, também constitui uma aprendizagem autêntica, uma espécie de "formação mútua". Há registros do funcionamento da Academia no Almanak Laemmert até o ano de 1865.

Os agentes docentes responsáveis pela sociedade, nomeados em reunião de 21 de julho por meio de eleição dos “funcionários”, podem ser vistos no quadro 6.

\begin{tabular}{|c|c|c|}
\hline Cargo & Nome & Docência \\
\hline Presidente & $\begin{array}{l}\text { João Antunes } \\
\text { da Costa e Silva } \\
(1860)\end{array}$ & $\begin{array}{l}\text { Nomeado em } 1842 \text { para cadeira de primeiras letras de Santa } \\
\text { Cruz; removido em } 1858 \text { para Sant'Anna; removido em } 1861 \\
\text { para Glória; falecido em 06/03/1863. }\end{array}$ \\
\hline \multirow[b]{2}{*}{ Vice-Presidente } & $\begin{array}{l}\text { José Alves Car- } \\
\text { neiro }(1860)\end{array}$ & Professor público em Niterói. \\
\hline & $\begin{array}{l}\text { Francisco Anto- } \\
\text { nio Augusto de Sá } \\
(1862)\end{array}$ & $\begin{array}{l}\text { Nomeado para cadeira de Inhaúma em 19/12/1837 (Correio } \\
\text { Oficial, 19/01/1838); removido em } 1855 \text { de S. José para S. } \\
\text { Antonio; falecido em } 28 / 11 / 1866 \text {. }\end{array}$ \\
\hline $1^{\circ}$ secretário & $\begin{array}{l}\text { João José Moreira } \\
(1860)\end{array}$ & $\begin{array}{l}\text { Nomeado em } 1849 \text { para cadeira de Inhaúma; removido em } \\
1855 \text { para Sant'Anna; falecido em 16/08/1873. }\end{array}$ \\
\hline $1^{\circ}$ secretário & $\begin{array}{l}\text { José Bernardes } \\
\text { Moreira }(1860)\end{array}$ & $\begin{array}{l}\text { Nomeado para } 2^{a} \text { cadeira de Santa Rita em } 1858 \text {; jubilado em } \\
14 / 01 / 1888 \text {. }\end{array}$ \\
\hline Tesoureiro & $\begin{array}{l}\text { Candido } \\
\text { Matheus de Faria } \\
\text { Pardal (1860) } \\
\end{array}$ & $\begin{array}{l}\text { Nomeado para } 1^{\text {a }} \text { cadeira de Santa Rita em 1837; jubilado em } \\
1874 .\end{array}$ \\
\hline \multirow{2}{*}{ Procurador } & $\begin{array}{l}\text { Bacharel Joaquim } \\
\text { Fernandes da } \\
\text { Silva }(1860) \\
\end{array}$ & $\begin{array}{l}\text { Nomeado em } 1855 \text { para cadeira da Lagoa; removido em } 1856 \\
\text { para S. José; removido em } 1867 \text { para S. Antônio; jubilado em } \\
\text { 14/01/1888. }\end{array}$ \\
\hline & $\begin{array}{l}\text { José Joaquim } \\
\text { Xavier (AL, } \\
1864)\end{array}$ & $\begin{array}{l}\text { Nomeado em } 1861 \text { para freguesia de Santana ( } 2^{a} \text { cad.) e jubilado } \\
\text { em 19/07/1884. }\end{array}$ \\
\hline $\begin{array}{l}\text { Membro adjunto } \\
\text { da Comissão de } \\
\text { Estatuto }\end{array}$ & $\begin{array}{l}\text { Francisco Alves } \\
\text { da Silva Castilho } \\
(1860)\end{array}$ & $\begin{array}{l}\text { Nomeado em } 1849 \text { para cadeira do Campo Grande; jubilado } \\
\text { em 12/02/1887. }\end{array}$ \\
\hline $\begin{array}{l}\text { Membro adjunto } \\
\text { da Comissão } \\
\text { Econômica }\end{array}$ & $\begin{array}{l}\text { Joaquim Sabino } \\
\text { Pinto Ribeiro } \\
(1860)\end{array}$ & $\begin{array}{l}\text { Nomeado em } 1837 \text { para cadeira de Sacramento; removido } \\
\text { em } 1855 \text { para Inhaúma; removido em } 1857 \text { de Inhaúma para } \\
\text { Ponta do Caju (também chamada de } 2^{a} \text { cadeira de S. Cristóvão); } \\
\text { jubilado em } 28 / 03 / 1863 \text {. }\end{array}$ \\
\hline
\end{tabular}

Fonte: Quadro elaborado pela autora com base nos jornais da Hemeroteca Digital da Biblioteca Nacional. 
Nessa reunião, os professores se organizaram em duas comissões de estudos. Uma para estudar teoria do ensino, formada por Candido Matheus de Faria Pardal, Joaquim Sabino Pinto Ribeiro e Francisco Alves da Silva Castilho. Outra, para estudar prática de ensino, formada por João Rodrigues da Fonseca Jordão, Joaquim José Cardoso de Siqueira Amazonas e Joaquim Fernandes da Silva. Nesse grupo, havia professores que estavam há bastante tempo no exercício do magistério público primário da Corte e que se conheciam de outros espaços, como no caso de João José Moreira e Pardal que atuaram juntos em bancas examinadoras, foram signatários em 1871 do Manifesto dos Professores da Corte e que também formaram a comissão responsável pela folha $A$ verdadeira Instrução Pública (15 ago. 1872).

De um modo geral, a mesa diretora era formada por professores que tinham um significativo tempo de experiência e agência na arte de ensinar e trabalhar nas contingências das escolas públicas e dos espaços da Corte, e por alguns novatos, cujo convívio poderia propiciar a transmissão de saberes entre gerações, mas também de "culturas de sobrevivência" (Bhabha, 1998). Cabe destacar que uma das reuniões teve como endereço, divulgado no Correio Mercantil (10 ago. 1860), a Rua dos Ciganos, n. ${ }^{\circ} 32$. Segundo o Almanak Laemmert de 1862 seria o endereço da 2a Escola Pública da freguesia de Sacramento, onde lecionava Antonio Ignácio de Mesquita Júnior, ex-adjunto de Pardal. A reunião havia sido marcada para o sábado, às 6 horas da tarde, meia hora após término das aulas previsto pelo regimento, que neste dia da semana deveria ser de "recordação" das lições.

Esse mesmo grupo de professores também organizará um movimento de doação de parte do salário para o governo diante de uma "conjuntura crítica". Provavelmente, tinha a ver com um episódio que marcou o início da década de 1860 e que teve o seu ápice no início do ano de 1863, a Questão Christie. A oferta de $5 \%$ dos seus ordenados por um ano foi conclamada aos "professores e professoras da Corte” em nota de jornal (Correio Mercantil, 6 fev. 1863). A agência de professores em questões de política internacional também se deu no caso da Guerra do Paraguai, para a qual também contribuíram com $5 \%$ dos ordenados.

Abordadas a seguir, a nomeação, exoneração e jubilação constituem etapas burocráticas da carreira docente que também foram atingidas de forma mais minuciosa pelo reordenamento jurídico de 1854. A reforma igualmente propiciou, mesmo sem estar na letra da lei, a emergência corriqueira de outros procedimentos burocráticos, a remoção e a permuta. 


\section{Nomeação: "Prestaram juramento e tomaram posse de seus cargos"}

Dom Pedro por graça de Deus e Unânime Aclamação dos Povos, Imperador Constitucional e Defensor Perpétuo do Brasil, faço saber ao que esta minha Carta virem, que de conformidade com o disposto no artigo 41 do Regulamento que baixou com o decreto N. 1331 A de 17 de fevereiro de 1854, Hei por bem nomear o professor...

A “Imperial Carta” que, nessa epígrafe, dizia respeito à nomeação do professor José Joaquim Xavier (AGCRJ, códice 10.4.35, 1862, f.34), com base no privilégio obtido por ter sido habilitado no $3^{\circ}$ ano da classe dos adjuntos, era o documento que efetivava o provimento das cadeiras. Aprovados em concurso público, habilitados no $3^{\circ}$ ano de adjuntos ou inseridos por meios não previstos em lei, a nomeação de um professor era cercada de regras e uma delas dizia respeito à sua conduta. Segundo o Regulamento de 1854 , não poderia “ser nomeado professor público o indivíduo que tiver sofrido pena de galés ou acusação judicial de furto, roubo, estelionato, bancarrota, rapto, incesto e adultério, ou de outro qualquer crime que ofenda a moral pública ou a Religião do Estado.” Em caso de igualdade de circunstâncias entre os candidatos aprovados, seriam preferidos para provimento das escolas (Art. 23), nesta ordem:

$1^{\circ}$ Os professores do primeiro grau para as do segundo, tendo leccionado com distinção por três anos.

$2^{\circ}$ Os professores adjuntos que ainda não estiverem nas circunstâncias do Art. 39 , mas houverem praticado satisfatoriamente por 3 anos.

$3^{\circ}$ Os professores particulares que por mais de 15 anos tenham exercido o magistério com reconhecida vantagem do ensino.

$4^{\circ}$ Os Bacharéis em letras, e os graduados em qualquer ramo da instrução superior do Império.

$\mathrm{O}$ artigo estipulava uma hierarquia entre os candidatos aprovados e que estivessem “em igualdade de circunstâncias”. Não obstante, é possível ver na documentação que candidatos com nota maior poderiam ser preteridos em favor de outro por justificativas diversas, pautadas na livre interpretação da lei, levando ao questionamento por parte dos candidatos. Nesse sentido, a composição da banca examinadora poderia ser determinante para aprovação, mas também nomeação. Entre as bancas de concurso público das quais Pardal participou, se encontra a 
do concurso para a escola do sexo feminino da freguesia da Ilha do Governador. Entre as candidatas, estava Anna Joaquina da Costa Passos, esposa do substituto Marcos Bernardino da Costa Passos, que, equiparado a adjunto, atuou na escola de Pardal. Anna Joaquina disputava a cadeira com Joanna Amália de Andrade e a banca, formada também pelo professor João José Moreira, concluiu que

A comparação destas e da prova oral em que também melhor se desenvolveu a opositora D. Anna Joaquina da Costa Passos, induz a Comissão a colocá-la em primeiro lugar, sem, contudo desconhecer, que a outra opositora não faltam habilitações que constituem a capacidade profissional para o ensino de primeiras letras. Sala de exames na Secretaria do Estado dos negócios do Império, em 11 de dezembro de 1856.

Anna Joaquina foi nomeada nesse mesmo ano para Ilha do Governador, onde lecionava seu marido, nomeado um mês antes para a cadeira de meninos. Joanna continuou atuando como adjunta, tendo "servido interinamente" na cadeira de Paquetá que veio a ser posta a concurso, do qual também participou, sendo aprovada, nomeada e tendo, logo em seguida, permutado a cadeira com outra professora, ilustrando uma movimentação dinâmica pelas escolas da Corte.

Porém, antes de "tomar posse", havia outro procedimento. Era preciso prestar "juramento aos santos evangelhos"

Pelo que mando ao Conselheiro de Estado [Eusébio de Queiroz] Inspetor Geral da Instrução Primária e Secundária do Município da Corte lhe dê posse da mencionada Cadeira, prestando o juramento aos Santos Evangelhos de bem cumprir seus deveres, do que se fará assentamento nas costas desta Carta que para firmeza, e que se cumprirá como nela contém (AGCRJ, códice 10.4.35, 1862, f. 34).

O juramento também era registrado na própria carta de nomeação. Uma forma de manter a memória do compromisso assumido com o Estado e com Deus no documento que lhe deu a investidura do cargo. O procedimento só foi alterado com a Reforma Leôncio de Carvalho, em 1879, que determinou pelo artigo 25 que o juramento seria "prestado conforme a religião de cada um, e substituído pela promessa de bem cumprir os deveres inerentes aos mesmos graus e funções, no caso de pertencer o indivíduo a alguma seita que o proíba”. 
Apesar da abertura para praticantes de outras religiões, ser nomeado poderia não ser uma tarefa fácil, como no caso da professora judia Stella Nahon que foi preterida, mesmo tirando o primeiro lugar no concurso para cadeira de São Cristóvão em 1884 (Lobo, 2000). Stella prestou novo concurso no ano seguinte e conseguiu ser nomeada para a $3^{\text {a }}$ cadeira do Engenho Novo, mas o fato assinala que, apesar da lei, a banca era composta por sujeitos que detinham poderes suficientes para sujeitar o resultado do concurso a outros critérios que não fossem apenas as notas.

O momento de nomeação também poderia ser considerado uma honra, manifestada por discurso como fez o professor Joaquim Sabino Pinto Ribeiro "ao dar posse ao novo professor" Antonio Pinto da Costa Souza Brandão, na escola da freguesia de Inhaúma. A "cerimônia", registrada em jornal de grande circulação, contou com a presença do professor sucessor e do sucedido, mais o delegado, os alunos e um senhor, Pedro Medella, "que se dignou com sua presença aumentar a solenidade do ato", no qual um aluno também recitou um soneto (Correio Mercantil, 7 fev. 1858). Não encontrei outros registros em jornais de realização de "cerimônias" como essa, mas o evento poderia configurar uma tentativa de instaurar um rito formal de iniciação.

Por outro lado, observam-se candidatos aprovados e indicados para nomeação desistindo da vaga. A professora Maria Thomazia de Oliveira e Silva, tendo prestado concurso para a cadeira de Paquetá, foi nomeada em 1855, mas declarou que não poderia ficar por razões de família. $\mathrm{O}$ decreto seguinte a nomeou então para a $2^{\text {a }}$ cadeira do Engenho Velho (Relatório da IGIPSC, 1856). Seria uma estratégia da candidata para ser nomeada para uma região de sua conveniência, sabendo da existência de uma possível vaga na localidade? Ou seria um sintoma da preocupação do governo em não perder uma professora aprovada diante da crítica falta de candidatos habilitados nos concursos?

Outro caso ocorreu quando a já mencionada professora Francisca de Paula Moraes e Lima, da freguesia de Santa Rita, foi jubilada. Sua sobrinha, Maria Arabella de Castro Tostes, que era adjunta na mesma escola, foi nomeada para assumir a vaga. Quando sua tia saiu da escola, Maria Arabella a encontrou sem as cadeiras:

[... a casa da Escola hoje inabitada pela mudança da referida Professora e minha tia, não tem os bancos necessários para receber meninas, porque estas retirarão suas cadeirinhas de que (por antigo uso e ser propriedade delas) se serviam, logo que tiveram notícia da mudança da professora (códice 11.3.27, 20/05/1871, f. 163). 
Maria Arabella também tinha outro argumento para não assumir a regência: o fato de não ter quem pudesse acompanhá-la até à escola. Assim, dois problemas a levaram a rejeitar o posto, a indisponibilidade da família e a falta de mobília na escola. $\mathrm{O}$ segundo também fazia parte da experiência de vários professores nomeados que relatavam a falta de objetos e mobília para entrar em exercício. Outros precisavam procurar um prédio para instalar a escola. Tais dificuldades se apresentavam em outras províncias, como na de São Paulo, em que professores também encontravam as escolas desequipadas, e onde, no início do século XX, ainda era possível observar professores responsáveis por procurar um prédio para a escola (Alcântara, 2014).

Outra situação complicada era a do substituto se recusar a "entregar” a escola ao professor recém-concursado, como no caso de José Theodoro Burlamaque. $\mathrm{O}$ professor deveria, primeiro, se apresentar ao delegado da instrução para assumir a cadeira da freguesia de Irajá, mas este havia sido demitido. Burlamaque então se dirigiu à escola para interpelar o professor substituto, que não quis entregar a regência porque a portaria de nomeação de Burlamarque era destinada ao delegado e não a ele (AGCRJ, códice 10.4.38, 19/05/1856, f. 4).

Portanto, procurar prédios, montar uma escola e reclamar para entrar na sala da aula poderiam fazer parte dos protocolos culturais e ritos de iniciação oficiosos que configuravam o momento em torno da nomeação para cadeira. Porém, também era uma oportunidade de agência docente, tendo em vista certa margem de poder decisão que, por exemplo, a escolha do prédio da escola, ainda que restrita, daria ao professor. $\mathrm{O}$ aparecimento de uma escola em uma determinada localidade, sua instalação e seu equipamento podem ter relação estreita com as intermediações engendradas pelo professor em nível local.

\section{Remoção e permuta: o rodizio como "cultura de sobrevivência"}

Cardoso (1999) ressalta que a transferência de lugar era caso excepcional nas primeiras décadas do século XIX e, de fato, na primeira metade do século foram poucos os casos de remoção identificados na pesquisa, como o de Venancio José da Costa, que em 1837 conseguiu transferência da freguesia de Santa Rita para a de Paquetá, e o de Francisco Joaquim Nogueira Neves, também em 1837, de Sacramento para a Glória. Contudo, havia outro caso que aparentemente seria mais complicado, o de transferência entre cidades: a remoção de José Maria Mafra, professor de ensino mútuo na Vila de Parati que conseguiu ser removido para a 
freguesia de São José na Corte (Correio Oficial, 06 mar. 1837, p. 206). Talvez seja também a situação de José de Moraes, professor da freguesia de Nossa Senhora do Pilar de Iguassu antes de assumir a cadeira da Ilha do Governador na capital.

No entanto, após a Reforma de 1854, observa-se o oposto. Um grande volume de remoções ocorre como se existisse uma insatisfação geral dos professores com seu local de trabalho. A maior parte do conjunto dos professores e professoras, após 1854, pediu remoção pelo menos uma vez até o final do Império (ver apêndices 1 e 2). Dos docentes que não pediram a remoção (ou que não consta oficialmente o pedido), vários foram exonerados ou morreram com pouco tempo de atuação. Poucos foram aqueles que permaneceram na sua cadeira de origem por toda trajetória, como Pardal e Francisca, na freguesia de Santa Rita. É bem verdade que, se por um lado, Pardal não mudou de escola, a escola mudou de lugar inúmeras vezes (apêndice 5).

Nem sempre a remoção era aceita rapidamente, como no caso de João Rodrigues da Fonseca Jordão, que foi removido da cadeira da freguesia suburbana de Irajá para a urbana de São José, por Decreto de 14 de dezembro de 1855 . Um jornal classificou a remoção como "um ato de justiça feito a este hábil professor, que já tinha sofrido duas preterições” (Diário do Rio de Janeiro, 18 dez. 1855).

Em alguns casos, fica mais evidente a relação entre remoção e dificuldade de acesso, como nos das escolas das freguesias da Ilha do Governador e da Ilha de Paquetá, onde a maior parte dos professores nomeados não permanecia nem dois anos, pedindo remoção logo em seguida. As duas freguesias pareciam servir como porta de entrada no ofício de professor público, não fazendo parte dos planos de estabelecimento de carreira. Como havia sempre uma cadeira vaga no continente, a remoção não tardava a ocorrer. Os professores que mais tempo ficaram nesses lugares, José de Moraes (1834-1859) e Venâncio José da Costa (1837-1856), respectivamente da Ilha do Governador e de Paquetá, foram nomeados e atuaram, na maior parte do tempo, na época em que remoção não era algo comum.

Outro procedimento corriqueiro para mudar de escola era a permuta, que requeria conhecer outro interessado. A permuta, ao contrário da remoção que dependia da vacância das cadeiras, demandava apenas um acordo entre os professores interessados e a autorização do governo. Elisa Tanner, da freguesia de Santana, e Amália Justa dos Passos Coelho, da freguesia de Santo Antonio, permutaram as cadeiras em 1872. Elas estiveram juntas no concurso que prestaram em 1855 , onde possivelmente se conheceram, caso isso não tenha se dado anteriormente. Amália Justa requereu a permuta mais 
de uma vez. Ela consta nos relatórios como membro de bancas examinadoras nos concursos públicos, na parte concernente ao magistério feminino, e teve várias alunas que se tornaram adjuntas (ex. Relatório da IGIPSC, 1869, p. 6). Ela também participou de comissões para avaliar livros, discutir o regimento interno e foi responsável pela comissão que forneceu argumentação para alteração do horário de funcionamento nas escolas de meninas, conforme assinala o Relatório de 1859.

Embora não tivesse nenhum item que regulasse a remoção ou permuta, o Regulamento de 1854 parece ter provocado o efeito, ou ao menos, favorecido o "rodízio das cadeiras". Talvez, mesmo sem tratar do assunto, a criação de um regulamento para a instrução, procurando centralizar e profissionalizar o serviço burocrático por meio da Inspetoria, tenha propiciado a emergência de estratégias oficiais, bem como de outras oficiosas, favorecendo também a agência de professores no intuito de defender seus interesses. O trânsito por diversas regiões da cidade permitia ao professor ter mais conhecimento do terreno no qual operava e, de algum modo, fortalecer as agências docentes e os laços de solidariedade entre os colegas, pois as questões reclamadas por um poderiam ser melhor compreendidas por outros que já teriam passado pela mesma região. O conhecimento adquirido pelo "rodízio das cadeiras” também poderia conferir ao professor uma experiência importante para atuação na vida social e política da cidade.

\section{Exoneração: "Fatos que motivaram a minha demissão..."}

A exoneração era uma forma de deixar o magistério público que se dava a pedido do professor ou por ordem do governo. Porém, ela não implicava o abandono da docência. Uma busca em outras fontes aponta que alguns exonerados continuaram no ofício em outros espaços, como nas escolas privadas. A exoneração também era o quinto instrumento de punição nos processos disciplinares previsto no Regulamento de 1854. A lista de penas era formada por admoestação, repreensão, multa, suspensão de exercício e vencimentos por até três meses e perda da cadeira. As três primeiras podiam ser impostas pelo Inspetor Geral e as duas últimas apenas por deliberação do Conselho Diretor.

Um caso de exoneração que gerou certa repercussão foi o de Polycarpo José Dias da Cruz, professor da escola da freguesia de Sacramento. Ocorreu por ordem do governo por Decreto de 18/03/1858, apesar de constar no relatório 
da Inspetoria que teria sido exonerado a pedido do professor. O procedimento causou polêmica, rendendo inúmeras notas de jornais ao longo de vários meses no Correio Mercantil do ano de 1858. A localização das notas nos apontou que as motivações da demissão têm a ver com as relações estabelecidas pelo professor, entre as quais as dos desafetos. Polycarpo recorreu aos jornais para denunciar que a exoneração teve motivos políticos e foi pautada nas desavenças com um antigo amigo, com o qual realizou estudos de latim. O sujeito teria se tornado seu opositor e, para agravar a situação, ocupava o cargo de delegado da instrução da freguesia onde lecionava. $O$ professor alegava que processo havia sido instaurado sem que ele tivesse sido notificado e convocado para prestar esclarecimentos, conforme previsto nos artigos 126 e 127 do Regulamento. Portanto, nem ele sabia dos motivos da demissão, o que o levava a questionar a validade jurídica do procedimento (Correio Mercantil, 28 mar. 1858).

O professor Polycarpo afirmava que sua "consciência" não o acusava de ter cometido falta e que a única exceção "era ter incorrido no desagrado do Sr. Dr. Francisco Lopes de Oliveira Araujo, delegado da instrução do $4 .^{\circ}$ distrito, não por fatos meus, porém por desavenças que na última eleição tive com um dos meus irmãos" (Correio Mercantil, 28 mar. 1858). O professor também ironizava o delegado por pensar que o motivo de sua demissão nunca chegaria ao seu conhecimento: "julgou que eu seria ferido como o viajante descuidado que cai na estrada assassinado sem ver o sicário que oculto no bosque lhe assestou o tiro!" Mas, para se defender, Polycarpo conseguiu informaçóes sobre a representação, feita pelo delegado, que motivou o processo disciplinar (Correio Mercantil, 5 jun. 1858): 
Figura 9 - Trecho de texto publicado pelo professor Polycarpo sobre as acusações que recebera

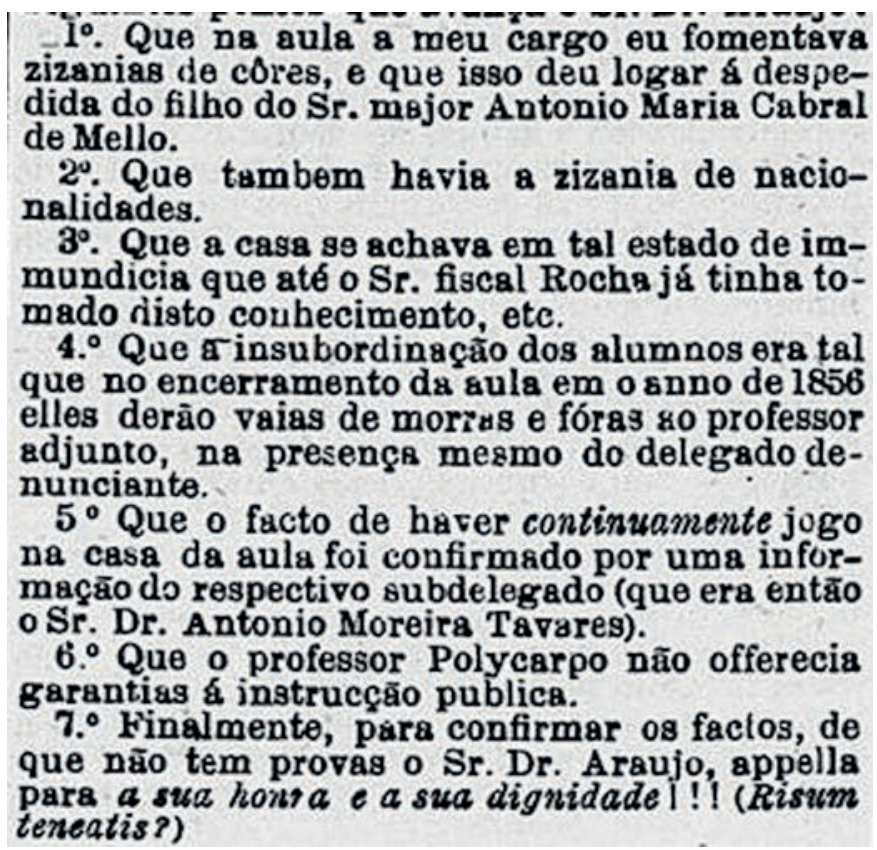

Fonte: Correio Mercantil, 05 jun. 1858, Biblioteca Nacional.

O professor se defende de cada uma das acusações do Dr. Araújo "esse médico sem clínica”, recorrendo à declaração de testemunhas e aos próprios sujeitos citados pelo delegado, como o major Cabral de Mello que informou não ter sido este o motivo da retirada de seu filho. Por outro lado, as acusações e as defesas mostram detalhes ricos da rotina de uma escola pública no século XIX. A "zizânia" - desarmonia - de cores e de nacionalidades da qual Polycarpo era acusado de promover aponta a diversidade étnica da sua escola, detalhada no texto da sua defesa (Correio Mercantil, 5 jun. 1858). Contra a acusação de constante ausência que ocasionava a desordem no estabelecimento, relatou seu empenho na manutenção da ordem escolar. Afirmou ter contratado um "guarda-porão" usando parte do seu "exíguo ordenado" para vigiar a entrada e saída dos alunos e contou que, em meados de 1856, descobriu

[...] que havia uma malta de trinta e tantos capoeiras na aula, tendo o seu quartel-general em uma casa da rua da Imperatriz; sabe que castigando tais alunos, extingui 
os capoeiras, indo até pessoalmente a casa censurar o dono pelo seu procedimento, que aliás se desculpou castigando severamente seu filho que era um dos da malta, e dizendo que ignorava que se guardavam em suas casas varas, juncos, insígnias e etc. (Correio Mercantil, 18 abr. 1858).

O número de trinta maltas na aula impressiona, bem como a reação do professor. Polycarpo havia sido fiscal suplente da freguesia de São José até maio de 1856, o que poderia lhe dar experiência e certa autoridade para fazer abordagens, como esta que relata ter feito na casa acusada de sediar maltas. Apesar de todo investimento na discussão que resultou numa série de artigos, Polycarpo havia declarado, talvez por estar com seus brios feridos, que não pretendia ser reintegrado à cadeira. Queria apenas apresentar sua defesa, conforme lhe dava o direito o Regulamento.

Após sua saída do magistério público, Polycarpo continuou atuando na docência, em escolas particulares, atividade que exercia antes de ser nomeado professor público, e passou também a dar lições de gramática portuguesa aos "aspirantes a emprego público" (Correio Mercantil, 22 ago. 1862), o que denota a existência de uma atividade de ensino voltada para concursos no século XIX. A presença de Polycarpo nas salas de aula das escolas públicas não se encerrou com sua demissão, pois anos depois uma gramática de sua autoria foi aprovada para uso nas escolas. Ao ter sido escolhida no lugar de outra gramática, escrita por ilustres conhecidos da sociedade, gerou uma reação dos jornais em defesa dos autores da gramática preterida e de ataque aos pareceristas. A gramática rejeitada havia sido escrita pelos senhores Vergueiro e Pertence e reprovada por uma comissão de quatro professores públicos primários - Candido Matheus de Faria Pardal, João José Moreira, José Bernardes Moreira e Luiz Thomaz de Oliveira - encarregada, pela Inspetoria Geral de Instrução Primária e Secundária da Corte, de avaliar diversos compêndios para adoção nas escolas. O Diário do Rio de Janeiro franqueou as colunas do jornal aos quatro professores a fim de publicarem artigos que justificassem o parecer dado. Assim, tinha início um debate eivado de provocações que persistiu por várias semanas no referido jornal de publicação diária. Envolvendo jornais, "ilustres" conhecidos e anônimos da sociedade carioca, o embate colocou em discussão a competência de professores, as relações de poder e o papel da imprensa em questões pedagógicas (Borges e Teixeira, 2013 e Teixeira, 2015). 


\section{"Seu espirito luzirá eternamente"}

Os vivos devem esperar pela justiça que mais cedo ou mais tarde será feita, como dizia o próprio finado, cujo espírito não se retirou inteiramente deste mundo, pois que nele ficou "o fruto de seus pensamentos, trabalhos e cogitações" (A instrucção pública, $1 .^{\circ}$ set. 1873 , por ocasião da morte de João José Moreira).

A morte também pode dizer muito sobre as atividades dos vivos. Os efeitos da vida esvaecida podem se perpetuar, mas em consonância com a experiência de outros sujeitos e de suas apropriações. Alguns professores tinham ideias e obras publicadas que continuaram a ser adotadas nas escolas após a morte.

Durante a pesquisa foi possível observar que a morte em serviço mobilizava professores em vários sentidos. Era motivo de lamento, solidariedade, agência e reivindicação. Alguns haviam trabalhado no dia da morte conforme assinala, por exemplo, o Relatório da Inspetoria referente ao ano de 1865: "Falleceu também, na noite de 26 do presente Abril, tendo lecionado no mesmo dia, o professor da primeira cadeira da mesma Freguezia de S. Christovão, Joaquim José Cardoso de Siqueira Amazonas" (Relatório da IGIPSC, 1865, p. 2).

No caso daqueles que já haviam se aposentado e que não exerciam uma atividade de destaque na sociedade ou que haviam sido relegados ao ostracismo, a morte talvez causasse menor comoção. O professor João Marciano de Carvalho, jubilado em 1884, por exemplo, segundo nota de jornal, morreu aos 92 anos, solteiro, sem parentes e sem assistência médica, de marasmo senil (O Paiz, 26 abr. 1894).

A morte em serviço causava maior comoção. Lamentava-se a perda de um bom professor, de um professor jovem - como Luiz Thomaz de Oliveira "falecido subitamente na flor da idade” (Relatório da IGIPSC, 1864) -, um professor sábio, pai de família. Eram muitas as razões para lamentar e, ao lamentar, retratava-se aspectos da trajetória do professor narrada a partir do fatídico acontecimento. A morte de João José Moreira trouxe vários destes aspectos: "Foi bom pai, bom esposo, bom amigo, bom cidadão e um dos melhores educadores da infância e estes documentos é que valem para o céu, onde, segundo o dizer do Apóstolo, ‘seu espírito luzirá eternamente”' (A Instrução Pública, 01 set. 1873).

E os professores, dentro dos ritos católicos, também se organizavam para garantir "luz" para as almas de seus falecidos colegas. 
A realização dos ritos funerários tem, pois, como função administrar a passagem que, por não ser instantânea, é um trajeto, um percurso em direção a um destino definido - e, muitas vezes, como no caso do cristianismo, permeado de provas e incertezas - que só termina ao fim da celebração dos rituais mortuários, que objetivam facilitar a viagem do morto (Rodrigues, 1997, p. 174).

Para tanto, era preciso arcar com os custos do chamado "sufrágio" da alma que, no caso das famílias dos professores, poderia ser demasiado oneroso para os salários que recebiam. Razão pela qual foi possível encontrar notícias da organização de subscrições pelos professores e da atuação, por exemplo, da Academia Pedagógica para angariar fundos para o sufrágio. Um último gesto de solidariedade da rede formada ao longo do exercício do magistério pelo professor falecido.

Figura 10 - Nota sobre missa fúnebre promovida pela Academia Pedagógica

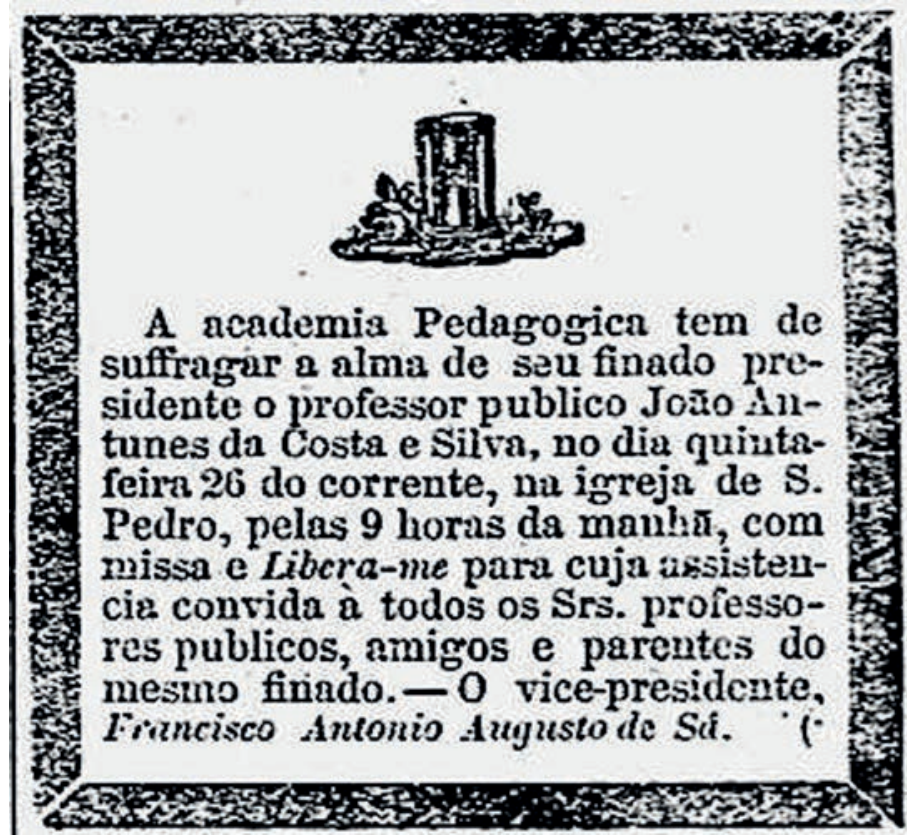

Fonte: Diário do Rio de Janeiro, 24 mar. 1863, Biblioteca Nacional. 
Figura 11 - Nota sobre subscrição para missa

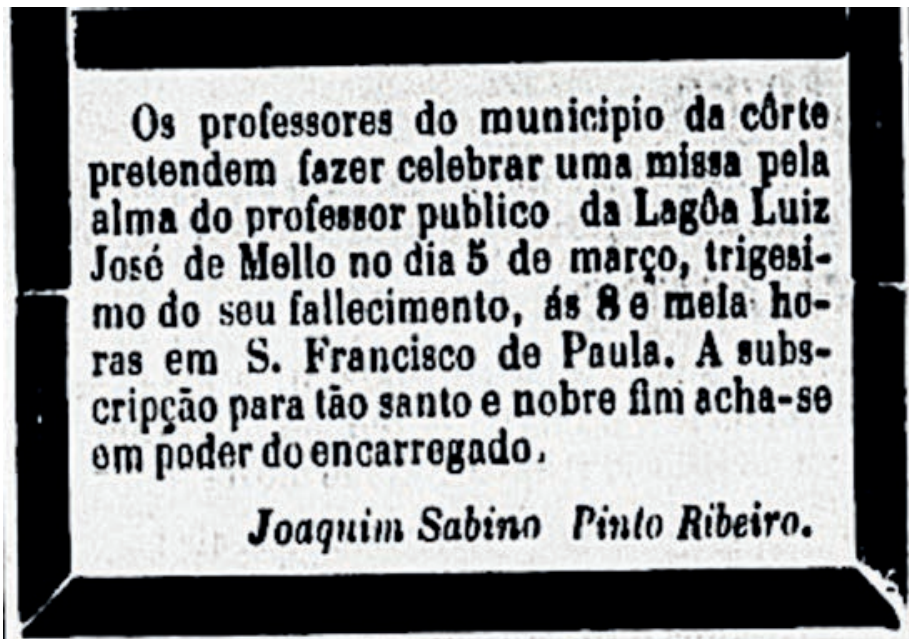

Fonte: Correio Mercantil, 23 fev. 1855, Biblioteca Nacional.

Figura 12 - Nota sobre subscrição para "sufrágio de alma” de professora

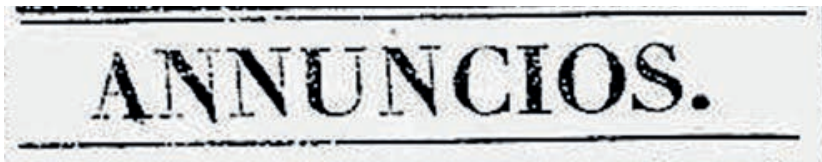

Sulscreverio espontanea e voluntariamente para sufiragar a alma da fallecida proiessora publice de primeiras letras da fregueria de Situt funa, os seus collegas a baixs declararlos:

Jnaquim Sabino Pinto Riheira

D. Clara Haria da Gloria IRlbeiro

Iosâ Roèzignes dàa Fonsêca Jordăo

D. Cathariua Lopes Curuja

A professora da Lagôn

Francisco Antonio Augusto de Si

D. Aunx Joaquina de Olivira e Silva.

Mlarcoe Beviaritino da liosta Passos João José Hloreira.

Esta subscriçăo prodnziăo a somma de - doze mil réis, quie toda foi offertada ao reverendo vigario da freguezia de Sant' Anna palo ancto religioso. 
Figura 13 - Nota sobre missa fúnebre para os professores Francisco Sá e Antonio Miranda

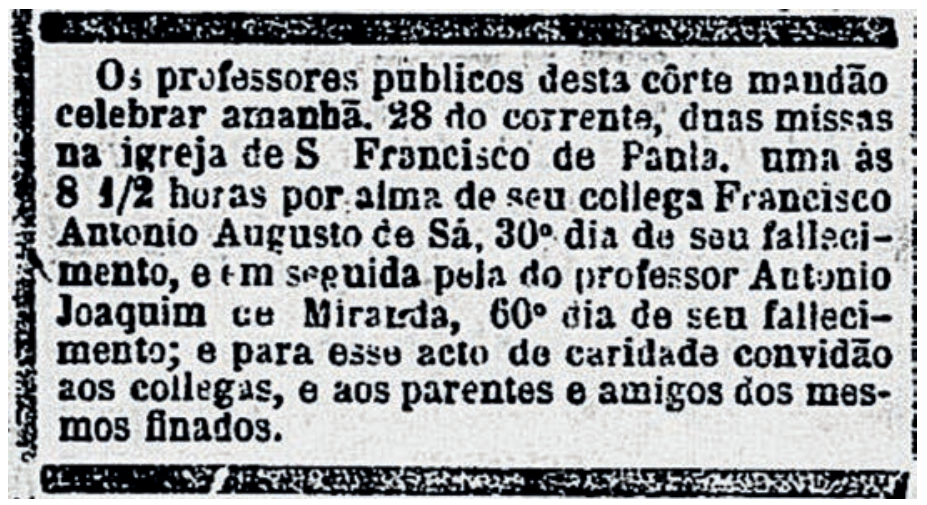

Fonte: Correio Mercantil, 27 dez. 1866, Biblioteca Nacional.

Professores também poderiam ser acionados para se responsabilizar pelo espólio do falecido. Felizardo Joaquim da Silva Moraes foi designado para cuidar da herança inusitada do professor primário particular Antônio da Silva Barker. Barker foi autor de obras e materiais usados nas escolas públicas da Corte, como os quadros caligráficos. Em seu testamento, Barker deixou os "utensílios de sua escola a um moço pobre e de boa conduta" que apresentasse um atestado de habilitações necessárias para exercer a função, assinado pelo respectivo professor responsável pelo espólio e mais dois de sua indicação (Diário do Rio de Janeiro, 08 out. 1852). Nesse caso, a herança do professor eram as suas ferramentas de ensino.

O legado era razão de preocupação dos professores. A morte ocasionava uma situação muito temida: a condição a que ficavam submetidas as famílias que perdiam o pai ou esposo professor. Os textos e notas em homenagem aos falecidos dizem muito da condição de penúria, que sensibilizavam os colegas receosos do mesmo futuro: "Morreu pobre, legando à esposa e aos filhos, digamos, a miséria e a caridade pública! Educador dos filhos do povo, entrega aos seus colegas os cuidados dos seus três filhos" (A Instrução Pública, 27 jul. 1873). O texto assinala a grande comoção causada pela morte de Mesquita e pelo estado de sua família: "mesmo egoístas a sentem por verem mais tarde em si o cumprimento de uma ordem eterna, a que não podem fugir”. Razão pela qual foi considerada um "ato de justiça" a licença para lecionar e dirigir escola concedida pelo Conselho Diretor da instrução à viúva, Deolinda Rosa Maria de Mesquita (A nação, 27 ago, 1873). Uma habilitação concedida a título de pensão. 
A morte poderia servir como metáfora para ilustrar vários sacrifícios aos quais eram submetidos na profissão docente e mostrar o descontentamento dos professores. O falecido João José Moreira foi retratado no texto escrito pelo professor Antonio Estevão da Costa e Cunha como uma pessoa modesta, de espírito reto e coração bondoso (A Instrução Pública, 01 set. 1873). Relata que ele era o professor "mais benquisto e respeitado dos seus colegas de um e outro sexo", a quem os professores recorriam para pedir conselhos atraídos por suas virtudes e experiência. Por gozar de confiança dos inspetores gerais, "viveu muito tempo sobrecarregado de comissões e serviços extraordinários desempenhando-os sempre com satisfação e louvor dos superiores”, em muitos dos quais trabalhou ao lado do professor Pardal. Desempenho esse que exigia demais do professor, cuja descrição retrata as condições de trabalho da docência fora da sala de aula:

Muitos dos pareceres que tinha de dar foram redigidos a horas mortas (?) da noite, após dias de insano trabalho, que mal produzia o necessário para sua família; e para o bom desempenho de outros lhe foi preciso muitas vezes sacrificar algumas horas desse mesmo trabalho, furtando assim um pouco de bem estar a si e aos seus (A Instrucção Pública, 01 set. 1873).

Costa e Cunha acusa o governo de ter esquecido o professor, apesar dos serviços prestados. Esquecimento não somente em torno de Moreira em particular, mas de toda categoria: "Todos os governos com que serviu esqueceram-no ou antes, nenhum governo se lembrou jamais do professorado primário senão para o massacrar".

Ao longo do texto fúnebre, Costa e Cunha aproveita para refletir, a partir da morte na pobreza, o futuro ao qual estava destinada a categoria. E lembra que Moreira tinha "espírito de classe": "Dotado de singular brio, possuindo este nobre atributo que se chama espirito de classe em um grau inexcedível doeu-lhe sempre e muito o depreciamento a que fora votado o magistério primário" (grifos do autor). O momento de luto, agravado pelas lamentáveis condições do magistério, leva ao professor a apelar para o colega que, em melhores condições, poderia zelar pelos companheiros na terra:

Pobres colegas! Infelizes companheiros de viagem tão escabrosa, vós aí ficais ainda, e ele se vai; ah! Mas quem tanto viveu na terra por vós não vos esquecerá no céu, de onde parece estar pedindo que não olvidemos os seus bons conselhos. Não os olvidemos pois... 


\section{Jubilação em uma "carreira honrosa e utilíssima"}

A saída do professor após cumprir um ciclo de atuação era um procedimento que tinha cinco artigos no Regulamento de 1854. Para ser jubilado com o "ordenado por inteiro" o professor precisava somar 25 anos de magistério, mas ele poderia ser jubilado a partir de dez anos de serviço, com vencimentos proporcionais. Essa parte do regulamento, que trata das condições e vantagens do magistério público, estabelece algumas questões importantes para se compreender a "carreira docente".

A palavra "carreira" para se referir à profissão era usada no período pelos professores e por políticos, como fica assinalada na imprensa:

E V.Ex. mesmo, abundando nessas ideias dizia há dias na câmara dos Srs. Deputados: 'As vantagens que dermos aos professores redundam em proveito do ensino' e logo depois: 'A vida do professorado é árdua, modesta e de verdadeira dedicação. É uma carreira honrosa e utilíssima: devemos torná-la, quanto pudermos, independente' (A Verdadeira Instruç̧ão Pública, 30 jul. 1872, grifos no original).

A palavra também é usada pelo professor Luiz Augusto do Reis, em outro momento no jornal, com o mesmo sentido: "a infelicidade de seguir essa carreira" ( $A$ Verdadeira Instruç̧ão Pública, 30 nov. 1872). Vantagens, independência e utilidade, palavras associadas à profissão que, juntamente, com a definição de etapas burocráticas, normas e benefícios atrelados ao tempo de serviço podem sinalizar o tom atribuído a uma concepção de carreira à época.

A primeira questão que merece ser destacada no aspecto da jubilação é que apenas seriam considerados vitalícios os professores que tivessem cinco anos efetivos de serviço. A vitaliciedade dava direito "ao adiantamento das quantias necessárias para entrarem para o Monte Pio, descontando-se-lhes mensalmente no Tesouro Nacional a quinta parte do ordenado até o pagamento integral dos cofres públicos" (Regulamento de 1854).

Depois, quando completassem dez anos de atividade, seus filhos teriam preferência para serem admitidos gratuitamente no Colégio de D. Pedro II ou no quadro de professores adjuntos. Aos quinze anos de serviço, uma "gratificação extraordinária" seria dada aos professores que houvessem se distinguido no ensino e aos 25 anos de trabalho o professor poderia ser "conservado" na função com aumento da quarta parte do ordenado. 
O termo "jubilado" em alguns momentos parecia consistir em uma honra pública, a coroação de uma vida profissional, pelo que pode ser visto em notas de jornais que destacavam a condição de jubilado para conferir maior prestígio ao professor. No entanto, a jubilação poderia também gerar frustação, como no caso da professora Francisca de Paula Moraes e Lima, citado no Manifesto dos Professores de 1871. Sem sua solicitação, foi jubilada pelo governo onze meses antes de completar 35 anos de magistério, perdendo assim o direito de ter uma gratificação destinada aos que, após completarem 25 de exercício, trabalhassem por mais dez anos.

A jubilação também se dava por requisição do professor ou por decisão do governo. Nos relatórios apenas há o registro de 35 jubilações até 1890, sendo alguns com menos de 25 anos de serviço. Essa é quantidade de sujeitos que levaram a "docência pública" nas escolas da Corte até o "final da carreira” durante o Império.

Pardal foi jubilado duas vezes. Primeiro na escola primária e depois no Imperial Colégio de D. Pedro II. A acumulação de jubilação foi motivo de consulta à Princesa Isabel, regente naquele momento por ausência do Imperador. O documento em que "Sua Alteza Imperial, a regente", autorizou a acumulação data de 20 de setembro de $1876 .{ }^{14}$

Após a jubilação, alguns professores também continuaram atuando, mesmo aqueles com mais de trinta anos de magistério, como o professor Pardal, nomeado diretor das escolas municipais e professor no colégio de meninas da Baronesa de Geslin, e Francisco Castilho, que se tornou inspetor do ensino na República. Os exemplos sinalizam o desenvolvimento de uma intensa atividade docente que extrapolava as salas de aula e que não se encerrava com a jubilação.

\section{Modus docendi: articulações e agências discursivas}

Preocupado com os problemas da instrução primária, o inspetor Eusébio de Queiroz, que atuou de 1855 a 1863, tinha a prática de convocar os professores para Conferências Pedagógicas previstas pelo Regulamento de 1854, mesmo com a falta de um regimento para sua realização. Em tais conferências também eram organizadas comissóes para os professores estudarem e darem parecer a respeito de diversos assuntos, como regimento interno, mobília e compêndios (Borges, 2008).

${ }^{14}$ Documento "Decisóes sobre assuntos relativos à Instrução" anexo ao Relatório do Ministro do Império do ano de 1876. 
Tal fato se torna significativo, menos pela solução dos problemas, uma vez que vários deles persistiram ao longo do tempo, e mais pela possibilidade de estabelecer relações interpessoais. É possível que tais conferências e reuniões de comissões tenham favorecido também a aproximação, a articulação e a agência de professores de diferentes freguesias, constituindo uma empatia e uma solidariedade no interior dos grupos, pois compartilhavam o mesmo papel de resolver questóes. Nesse sentido, cabe destacar que quando $O$ Correio da Tarde noticiou a realização da reunião, no Colégio de D. Pedro II, para formação de uma associação, em junho de 1857, conforme assinalado anteriormente, já haviam ocorrido conferências de professores e delegados (Relatório da IGIPSC de 1856, assinado em 21 de abril de 1857).

Uma das discussões que se desenrolou na gestão de Eusébio de Queiroz era quanto ao horário de funcionamento da escola em duas sessões diárias, que estava a cargo dos delegados fiscalizarem. A questão provocou tensões eivadas de traços de tradição entre delegados, professores e famílias.

O Regimento Interno de 1855 determinava que os trabalhos escolares seriam divididos em aulas da manhã e da tarde. Na parte da manhã, no verão, de $8 \mathrm{~h}$ às $11 \mathrm{~h}$, e no inverno, de $8 \mathrm{~h} 30 \mathrm{~min}$ às $11 \mathrm{~h} 30 \mathrm{~min}$. As aulas de tarde seriam sempre das $3 \mathrm{~h}$ às $5 \mathrm{~h} 30 \mathrm{~min}$. A determinação gerou uma série de documentos produzidos pelos que eram responsáveis por zelar pelo cumprimento da norma, por aqueles que deviam cumpri-la e por quem, de alguma forma, estava ligado à escola. Como o horário escolar afetava a organização da vida dos sujeitos, vários documentos, cujo assunto era o horário, acabavam por trazer aspectos da vida familiar e local.

Segundo Pintassilgo (2011, p. 19), “o trabalho dos professores está impregnado de tradição, o mesmo acontecendo em relação à vida das escolas" e os documentos sugerem que havia uma tradição das aulas com apenas uma sessão diária. Tradição enraizada tanto nos hábitos docentes quanto nos das famílias. A mudança trazia transtornos nas rotinas escolares e familiares, mexendo no âmbito privado $^{15}$ e mobilizando agências subalternas e de negociação. Houve embates de forças entre governo, professores, famílias e demais sujeitos envolvidos, que atravessaram pelo menos três décadas. Esses embates não significam a existência de duas forças opostas, estando o governo de um lado e famílias e professores de

${ }^{15}$ Gallego (2008) fez um aprofundado estudo sobre essa questão no caso paulista, também no século XIX, e Faria Filho (2000) sobre o caso mineiro. 
outro. A tensão articulou muitos sujeitos, de formas difusas, cada qual lidando e manejando de maneira diversa suas relações no tecido social.

O caso dos professores da freguesia da Lagoa, que não cumpriam o horário estabelecido, veio à tona somente 17 anos depois, em 1872, o que mostra a possível conivência do delegado da instrução. Diante de uma intimação feita pelo inspetor geral para que o delegado José Theodoro da Silva Azambuja explicasse a razão pela qual as escolas de sua jurisdição não funcionavam em duas sessões, ele responde: "tenho a expor a V. Ex.ia que quando entrei em exercício do cargo de Delegado deste distrito, em 1858, já encontrei essa praxe, que me custa ter sido autorizada em época anterior" (AGCRJ, códice 10.4.19, 06 jul. 1872, f.70). O delegado ocupava o cargo havia quatorze anos, tinha conhecimento da prática dos professores desde que entrou em exercício, e como autoridade competente e responsável pelo cumprimento das normas, não tinha tomado nenhuma medida contra essa tradição legalmente revogada.

Outra coisa que chama atenção é que os professores da freguesia da Lagoa naquele momento, Antonio Cypriano de Figueiredo Carvalho e José Antonio de Campos Lima, haviam sido nomeados após o Regulamento de 1854 e o Regimento de 1855 , ou seja iniciaram o magistério público quando a mudança já tinha sido instituída por lei. Desse modo, ao assumirem as duas cadeiras na freguesia da Lagoa, em 1865 e 1866, respectivamente, eles mantiveram a tradição existente do funcionamento das escolas em apenas um turno.

A segunda cadeira havia sido criada por Decreto de 11 de maio de 1866, por "perseverança do delegado" e montada "sem dispêndio do tesouro nacional”, com recursos oferecidos pela Irmandade da Capela de Nossa Senhora da Conceição por meio do dito delegado (Relatório da IGIPSC do ano de 1866). Portanto, a unidade escolar não viria de uma "tradição" daquelas que se constrói ao longo de vários anos de imersão na localidade, mas que poderia ser produzida, após sua abertura, por meio da transmissão do modo como os habitantes viviam na freguesia e lidavam com a escolarização, juntamente com a experiência do professor trazida de outros lugares.

Campos Lima havia sido adjunto do professor Pardal em 1860, conforme indicado no quadro 5, e Antonio Cypriano havia entrado no magistério em 1860 na cadeira da Guaratiba. Ambos professores, portanto, tiveram vários anos de contato com as práticas culturais da população em relação às escolas quanto em outros espaços, a ponto, por exemplo, de adotarem hábitos existentes antes da Reforma de 1854. No caso da professora da cadeira de meninas da Lagoa, Anna 
Euqueria Lopes Álvares, tendo sido nomeada um ano antes da reforma, em 1853, estava, portanto, há quase vinte anos na mesma escola, tempo que também permitira consolidar práticas tradicionais.

O “contato com o povo" permitiria ao professor o uso da retórica da compreensão para tratar da dificuldade dos alunos de voltarem para aula da tarde, pela "precária sorte da maior parte dos pais dos alunos que a frequentam, pois são geralmente pouco favorecidos da fortuna, muitos dos quais mandam com sacrifício seus filhos a aula de manhã e precisam que a tarde estejam em casa para os ajudar em seus serviços domésticos" (Professor Carlos Augusto Soares Brazil, AGCRJ, códice 10.4 .19 , f. 85); e pelo fato do horário interferir, por exemplo, no hábito da janta:

[...] também não é menos notável o fato de jantarem a horas diversas, do que resulta o grande inconveniente de virem uns depois da hora marcada para recomeçarem os trabalhos escolares, e outros deixarem de vir, muitas vezes por alguma circunstância os haver obrigado a jantar mais tarde (AGCRJ, códice 10.4.19, f. 85).

Entretanto, a dificuldade para ajustar a rotina escolar com o hábito da janta também era dos professores. O delegado da freguesia do Espírito Santo, vigário José Alves Pereira, ao comentar quatro explicações dadas pelo professor Gustavo José Alberto para lecionar somente pela manhã, ressalta esse aspecto: "A $1^{\text {a }}$ fundamenta no hábito de ter dado sempre aula em uma só sessão, e figura um perigo, imaginário, de dar-se aula depois do jantar. Este motivo não merece nenhuma ponderação" (AGCRJ, códice 10.4.19, 1872, f. 87-88). O motivo dado pelo professor se insere na perspectiva das tradições inventadas como "reações a situações novas que ou assumem a forma de referência a situações anteriores, ou estabelecem seu próprio passado através da repetição quase que obrigatória" (Hobsbawm, 2002, p. 10). Dar aula em uma só sessão e não trabalhar após a refeição constituem práticas que o professor vincula a uma continuidade com o passado.

Dessa forma, a relação compreensiva e de solidariedade dos professores com as famílias no caso dos horários pode levantar várias questões. Uma corresponde ao argumento da categoria docente de que o professor sabe o que é melhor em relação ao "povo"; outra, o fato de que os professores poderiam estar usando a tradição do "povo" para justificar seus interesses, a manutenção da tradição de aula em uma só sessão, conforme defendiam. 
A pressão das tradições, juntamente com as agências docentes e das famílias, que durante muito tempo organizavam a vida dos sujeitos escolares, fizeram com que o governo cedesse parcialmente ainda na década de 1850 . No relatório de 1856, o inspetor geral Eusébio de Queiroz narra a organização de comissões de professores e professoras, presididas por delegados, para discutir o regimento e, especialmente, modificações nas escolas do sexo feminino. E em relatório do ano de 1859, Eusébio anuncia a substituição do que determinava o artigo 22 do Regimento, a partir das "reflexões" nas conferências e das comissões. Com a aprovação do governo, por meio de um Aviso de 13 de julho de 1859, as aulas públicas para meninas passaram a funcionar em uma sessão diária, no verão de $8 \mathrm{~h}$ às $14 \mathrm{~h}$ e no inverno de $8 \mathrm{~h} 30 \mathrm{~min}$ às 14h30min. A questão também se aproxima das discussões trazidas por Thompson em torno da noção de costume que "constituía a retórica de legitimação de quase todo uso, prática ou direito reclamado” (2005, p. 16).

Em 1872, em um documento coletivo, assinado por vários professores, podemos encontrar os possíveis argumentos que foram usados para justificar a mudança do horário das escolas femininas, que teria ocorrido:

[... em virtude da dificuldade de que se queixam as Sras. professoras, no acompanhar as meninas, visto não ser prudente, no estado atual do país, deixar andar desacompanhadas meninas de certa idade, por ficarem expostas a muitos desacatos, de que nem sempre as livram as companhias empregadas pelos pais (Relatório da Inspetoria, 1872-2A, A-B20-4).

Percebemos que outro tipo de tradição, a de gênero - que impunha a condição de fragilidade e o recato à figura da mulher -, parece ter sido determinante na manutenção da prática escolar de uma única sessão de aula e, consequentemente, na negativa da inovação que colocava em risco o zelo necessário ao sexo feminino, o que, certamente, constituía uma tradição cara à sociedade da época. Por outro lado, também constituem argumentos usados pelas mulheres professoras nas negociações de seus interesses, fazendo parte de mais um exemplo de agência subalterna e igualmente de agência coletiva, na medida em que envolveu um conjunto significativo de professores. Interessado na estratégia cultural e nos confrontos políticos, Bhabha (1998) assinala que sujeitos insurgentes "criam" agências coletivas, sendo a solidariedade social forjada por meio de crises e contingências de sobrevivência histórica. 
Assim, a tensão continuou no caso das escolas de meninos. Mais de vinte anos depois do regimento, o assunto tornou-se um dos temas das Conferências Pedagógicas de 1876:16 "Convém que as escolas públicas de meninos funcionem diariamente em uma só sessão?”; e também entre os nove pontos da Conferência de 1878 (Códice 15.3.8, fs. 6-18.). A permanência do debate por tanto tempo corrobora o que nos chama atenção Agustín Escolano (2011, p. 22, tradução nossa):

Gabriel sublinhou, ainda, que não são apenas os professores, os pedagogos ou os políticos que constroem e ditam normas; também a sociedade e as famílias das crianças escolarizadas criam pautas e métodos que se transmitem no interior dos coletivos de sociabilidade não formal e na escola mesma. Esta cultura formativa popular se materializa em práticas que se socializam através da comunicação da tradição e que não se extinguem sob a pressão da cultura oficial ou acadêmica dominantes. ${ }^{17}$

Cabe destacar que as escolas municipais dirigidas por Pardal funcionavam em uma só sessão de $10 \mathrm{~h}$ às $14 \mathrm{~h} 30 \mathrm{~min}$, sinal de que era adepto do sistema de um turno de aula. Após a conferência de 1876, em relatório, o inspetor geral José Bento da Cunha Figueiredo se mostrou mais favorável à realização de apenas uma sessão nas escolas de meninos. Em ofício ao Ministro do Império, retifica sua ponderação sobre a questão: "Não só os professores, como alguns delegados, entendem que é muito inconveniente dar aula à tarde [...]. Não estou longe de pender para a opinião dos professores, mas a V.Ex. compete deliberar o que melhor entender sobre tal assunto" (Relatório da IGIPSC, 1877, p. 6-7).

A permanência do tema em pauta nos relatórios do governo, passados 22 anos, demonstra que a inovação se deparou com uma acentuada resistência, o que levou à proposta de que talvez fosse melhor ceder à tradição, reivindicada por pais e professores. Nesse momento, alguns delegados estavam mais sensíveis ao problema

\footnotetext{
${ }_{16}$ Fonte: A Escola- Revista... 1877. Cf. Borges, 2005.

${ }^{17}$ No original: "De Gabriel ha destacado, además, que non son solo los ensenántes, los pedagogos o los políticos quienes construyen y dictan normas; tambiém la sociedade y las famílias de los nińos escolarizados crean pautas y métodos que se transmiten en el interior de los colectivos de sociabilidade no formal y en na misma escuela. Esta cultura formativa popular se materializa en practicas que se socializan a través de la comunicación de la tradición y que no se extinguén bajo la presión de la cultura oficial o académica dominantes".
} 
e o inspetor geral praticamente concorda com os professores. Efeito dos debates dos primeiros anos da década de 1870? Enquanto as conferências convocadas pelo inspetor Eusebio (1855-1863) tinham um caráter menos formal, as conferências organizadas a partir de um regulamento específico (1872), em um período de grande efervescência política, eram constituídas de maior formalidade e contavam com a presença de pessoas consideradas ilustres na sociedade, como o Imperador D. Pedro II (Borges e Gondra, 2005). Essa reunião dos professores, frente a frente com a inspetoria e com sujeitos destacados da sociedade, poderia fazer com que os docentes procurassem ter uma articulação maior, proferissem discursos elaborados com uma retórica que visava favorecer seus interesses e, igualmente, operar certos jogos de poder que colocavam em cena suas relações, como veremos a seguir.

\section{"A erudição que neles transluz"}

Os anos das décadas de 1870 e 1880 constituem-se em um período que vários autores da historiografia da educação apontam como fértil de discussões em torno de temas educacionais e organização docente (Hilsdorf, 1977; Schueler, 2002 e Lemos, 2006). Na política, em 1870 foi fundado o Partido Republicano. Na profissão docente, na Capital, foi redigido o Manifesto dos Professores Públicos Primários da Corte de 1871, documento analisado por Schueler e por Lemos. A imprensa pedagógica emergiu com disputas (Villela, 2002b e Teixeira, 2015). Em 1872, foi estabelecido o Regulamento das Conferências Pedagógicas que, depois de um cancelamento, teve sua primeira ocorrência em janeiro de 1873 . No meio da agitação desses primeiros anos, nove professores e quatorze professoras foram nomeados para assumirem cadeiras de diversas localidades. Nos quadros 7 e 8 , observa-se a continuidade de uma quantidade expressiva de adjuntos nomeados professores públicos somente na década de 1870, antes do funcionamento da Escola Normal da Corte.

Quadro 7 - Professores nomeados na década de 1870. Os nomes em itálico indicam os que haviam sido adjuntos

\begin{tabular}{|c|l|c|l|}
\hline N. & Professor & $\begin{array}{c}\text { Ano de } \\
\text { nomeação }\end{array}$ & Final da docência \\
\hline 1 & José João de Povoas Pinheiro & 1871 & - \\
\hline 2 & Carlos Antonio Coimbra de Gouvea & 1871 & - \\
\hline 3 & Antonio José Marques & 1871 & Jubilado em 14/01/1888 \\
\hline
\end{tabular}




\begin{tabular}{|c|l|r|l|}
\hline 4 & David José Lopes & 1871 & Jubilado em 25/05/1886 \\
\hline 5 & Carlos Augusto Soares Brazil & 1872 & \multicolumn{1}{|c|}{} \\
\hline 6 & Augusto Candido Xavier Cony & 1872 & \multicolumn{1}{|c|}{-} \\
\hline 7 & Philippe de Barros Vasconcellos & 1872 & - \\
\hline 8 & Januário dos Santos Sabino & 1872 & - \\
\hline 9 & Candido Baptista Antunes & 1873 & - \\
\hline 10 & José Alves da Vizitação & 1874 & - \\
\hline 11 & Antonio Pinheiro do Aguiar & $1875 \mathrm{AL}$ & - \\
\hline 12 & Luiz Augusto dos Reis & 1875 & - \\
\hline 13 & Augusto José Ribeiro & 1875 & - \\
\hline 14 & Jorge Roberto da Costa & 1875 & Jubilado em 15/12/1890 \\
\hline 15 & Francisco José Gomes da Silva & 1875 & Jubilado em 15/12/1890 \\
\hline 16 & Agostinho José Soares Brazil & 1875 & - \\
\hline 17 & $\begin{array}{l}\text { Antonio Joaquim Teixeira de } \\
\text { Azevedo }\end{array}$ & 1875 & - \\
\hline 18 & José Joaquim de Amorim Carvalho & $1877 \mathrm{AL}$ & Exonerado em 27/01/1883 \\
\hline 19 & José da Silva Santos & $1878 \mathrm{AL}$ & - \\
\hline 20 & Domingos José Lisboa & $1878 \mathrm{AL}$ & - \\
\hline
\end{tabular}

Fonte: Quadro elaborado pela autora com base nos relatórios da IGIPSC, documentos manuscritos do AGCRJ e no Almanak Laemmert.

Quadro 8 - Professoras nomeadas na década de 1870. Os nomes em itálico indicam os que haviam sido adjuntos

\begin{tabular}{|c|l|c|l|}
\hline N. & Professor & $\begin{array}{r}\text { Ano de } \\
\text { nomeação }\end{array}$ & Final da docência \\
\hline 1 & Josepha Thomazia da Costa Passos & 1871 & - \\
\hline 2 & Amália Emilia da Silva Santos & 1871 & - \\
\hline 3 & Zulmira Elizabeth da Costa Cirne & 1871 & Jubilada em 15/12/1890 \\
\hline 4 & $\begin{array}{l}\text { Gertrudes Mathilde da Silveira } \\
\text { Em 1879 consta como Gertrudes da } \\
\text { Silveira Cardoso }\end{array}$ & 1871 & Falecida em 1879 \\
\hline 5 & Maria Benedita Lacé Brandão & 1871 & - \\
\hline 6 & Maria Gomes Santarém & 1871 & - \\
\hline 7 & $\begin{array}{l}\text { Luiza Joaquina de Queiroz Paiva } \\
\text { Mendes }\end{array}$ & 1871 & - \\
\hline
\end{tabular}




\begin{tabular}{|c|c|c|c|}
\hline 8 & Luiza Celestina Velloso & 1871 & Jubilada em 25/09/1886 \\
\hline 9 & $\begin{array}{l}\text { Francisca da Gloria Dias } \\
\text { Francisca da Gloria Dias Major } \\
(1873) \\
\text { Francisca Dias de Alvarenga Cunha } \\
(1880)\end{array}$ & 1871 & - \\
\hline 10 & Adelina Amelia Lopes Vieira & 1872 & - \\
\hline 11 & Claudina de Paula Menezes & 1872 & - \\
\hline 12 & Eudoxia Brasília da Costa & 1872 & Falecida em 06/05/1884 \\
\hline 13 & Thereza Maria de Jesus Bastos & 1872 & - \\
\hline 14 & $\begin{array}{l}\text { Polycena de Menezes Dias da Cruz } \\
\text { Araujo }\end{array}$ & 1872 & Falecida em 1882 \\
\hline 15 & $\begin{array}{l}\text { Guilhermina Emilia da Rocha } \\
\text { Guilhermina Azambuja Neves }\end{array}$ & 1874 & Falecida em 18/06/1883 \\
\hline 16 & $\begin{array}{l}\text { Maria Fortunata Siqueira Amazo- } \\
\text { nas Gomes da Silva }\end{array}$ & 1874 & - \\
\hline 17 & $\begin{array}{l}\text { Augusta Castellóes } \\
\text { Augusta Castellões Fernandes da } \\
\text { Costa }\end{array}$ & 1874 & - \\
\hline 18 & $\begin{array}{l}\text { Thereza de Alcântara da Costa } \\
\text { Pereira }\end{array}$ & 1874 & - \\
\hline 19 & Eudoxia dos Santos Marques Dias & 1874 & - \\
\hline 20 & Theresa Carolina Mirandella & $\mathrm{AL}, 1875$ & - \\
\hline 21 & Mathilde Carolina da Rocha & 1875 & Exonerada em 12/10/1878 \\
\hline 22 & Maria Arabella Fortes Guimaräes & 1876 & - \\
\hline 23 & Anna Camilla Alves Nogueira & 1877 & Falecida antes de tomar posse \\
\hline 24 & $\begin{array}{l}\text { Adelaide Augusta da Costa } \\
\text { Adelaide Augusta da Costa e Silva } \\
(1884)\end{array}$ & 1877 & Faleceu entre $1884 / 1885$ \\
\hline 25 & $\begin{array}{l}\text { Maria Magdalena da Silveira Faria } \\
\text { Depois, Maria Magdalena da } \\
\text { Silveira Carmo }\end{array}$ & 1877 & Exonerada em 29/09/1886 \\
\hline 26 & Anna Jacintha da Conceição Dias & $\mathrm{AL}, 1878$ & - \\
\hline 27 & $\begin{array}{l}\text { Elvira Cesar } \\
\text { Elvira Cesar Piragiba (AL, 1879) }\end{array}$ & AL, 1878 & - \\
\hline 28 & Anna América da Rocha e Souza & $\begin{array}{c}\text { Entre } 1877 \mathrm{e} \\
1879 \\
\end{array}$ & - \\
\hline 29 & $\begin{array}{l}\text { Marianna Angélica Loureiro } \\
\text { Fernandes }\end{array}$ & $\begin{array}{l}\text { Entre } 1877 \mathrm{e} \\
\quad 1879\end{array}$ & - \\
\hline
\end{tabular}




\begin{tabular}{|l|l|c|l|}
\hline 30 & Eduviges Carolina da Silva & 1879 & - \\
\hline 31 & Leobina Cardoso Rodrigues Lima & 1879 & Falecida em 08/06/1883 \\
\hline
\end{tabular}

Fonte: Quadro elaborado pela autora com base nos relatórios da IGIPSC, documentos manuscritos do AGCRJ e no Almanak Laemmert.

Podemos notar nos quadros mais uma geração de professores que iniciava a carreira no magistério público formada pela anterior, constituindo uma "cadeia" formativa. O aspecto pode ter corroborado com a "coesão" assinalada por Lemos (2006) quanto à emergência do movimento docente na corporação dos professores públicos da Corte. Cuidar da formação uns dos outros pode ter colaborado para gerar um espírito de cumplicidade, solidariedade e de coletividade que iria se refletir nas Conferências Pedagógicas e outros espaços. Nas duas listas também se encontram mais um grupo de professores que, quando adjuntos, foram examinados por Pardal, como: José João de Povoas Pinheiro, Antonio José Marques, Josepha Thomazia da Costa Passos (cujo nome de solteira era Gomes) e Zulmira Elizabeth da Costa Cirne (AGCRJ, códice 11.2.10, fs. 130-133, 72-73, 123-126, 209-212).

A agência coletiva fez parte significativa da trajetória de Pardal. Ele participou de sociedades docentes e organizou reunióes para discussão entre professores. O "estar-junto" pode favorecer a solidariedade e rearticulação de discursos e interesses dos professores, mas também da própria sociedade (Bhabha, 1998). Os professores já vinham se organizando e rearticulando discursos e ações em um processo constante de reinscrição e negociação com diferentes instâncias que permitiu a emergência de um "processo da agência tanto como desenvolvimento histórico quanto como agência narrativa do discurso histórico” (Bhabha, 1998, p. 266). Dessa forma, a produção de documentos resultantes das agências docentes pode configurar um processo de tradução e de ressignificação dos anseios, das representações, bem como das contradições inerentes a um grupo - com uma "vontade coletiva" e uma identidade em comum, a docência -, mas que não constitui um bloco homogêneo.

Na década de 1870, Pardal, juntamente com João José Moreira, foi signatário do Manifesto dos Professores Públicos de Instrução Primária da Corte, que teve como relator o professor Manoel Frazão. O Manifesto, um documento reivindicatório, foi endereçado à Assembleia Legislativa, ao Ministro do Império e ao Imperador, e posteriormente, em razão de não obterem respostas, encaminharam ao que chamaram de "poder real da nação", ou seja, a sociedade civil 
(Lemos, 2006). No manifesto, os professores apresentam uma narrativa de problemas do ofício de professor público nas últimas décadas, "classe talvez a mais importante dos servidores do Estado". Para discutir os baixos salários comparam com os de outras funções do serviço público, remetendo a leis de diferentes décadas, sendo a primeira de 1844. Exigiam respeito do poder público diante do diagnóstico de que "não há ministro novo que não diga no seu primeiro relatório que somos ignorantes”. Apesar de admitirem que depois os ministros "modificavam o seu juízo", tais fatos mostram a realização de uma abordagem com tom histórico a respeito dos problemas dos quais se queixavam e que desde sempre fizeram parte da vida dos professores que atuavam naquele momento. No texto, também estavam incluídas críticas ao dinheiro gasto com os novos, grandiosos e modernos prédios escolares que estavam sendo construídos, dos quais Pardal se tornaria diretor.

Segundo Lemos (2006), as autoridades chegaram a discutir os procedimentos punitivos que poderiam ser tomados contra os professores, mas pelo fato do Imperador ter defendido o direito à liberdade de expressão, foi sugerido que o Ministro do Império fizesse apenas uma repreensão por escrito.

No ano seguinte, o jornal pedagógico $A$ Verdadeira Instrução Pública, que tinha como redator o professor Manoel Frazão, em edição de 15 de agosto 1872 , registra que, em reunião de 17 de julho de 1872, ficou decidido que os negócios da folha seriam dirigidos por uma comissão de cinco membros, entre os quais se encontravam o redator Frazão, Pardal, João José Moreira, Antônio José Marques e Carlos Antonio Coimbra de Gouvêa. Cabe observar alguns aspectos das relações entre tais sujeitos. João José Moreira e Pardal atuavam juntos pelo menos desde a década de 1850, conforme já assinalado. Em artigo do Constitucional (09 ago. 1864), Frazão sinaliza uma relação de amizade com Pardal: “Tendo-me comunicado o meu digno colega e amigo o Sr. Candido Matheus de Faria Pardal". Antônio Marques havia sido adjunto na escola de Pardal e Carlos Coimbra havia sido adjunto na escola de Frazão, ambos na década de 1860. Nesse sentido, ter sido adjunto poderia favorecer sua inserção nas agências docentes. Portanto, o grupo de professores se conhecia muito bem, com vários anos de convivência.

$A$ Verdadeira Instrução Pública emergia em um momento de intensos debates educacionais em torno da instrução pública, envolvendo professores e representantes do governo conforme assinala Villela (2002b). A primeira edição do jornal foi lançada em 15 de junho de 1872 e pretendia combater as posições consideradas elitistas da folha $A$ Instrução Pública, lançada dois meses antes, 
chefiada por Alambary Luz, diretor da Escola Normal da Província, bem como se legitimar como representante da classe de professores primários (Villela, 2002b). Segundo Villela, $A$ Verdadeira Instrução Pública criticava a visão dos grupos que desmereciam a capacidade e experiência dos professores públicos primários. Ressalta a alegação do professor Frazão de não poder se tomar a exceção pela regra e que, se havia alguns professores despreparados, a culpa seria da Inspetoria que os aprovou e admitiu nas escolas.

Pardal também fez parte da comissão que tentou organizar o Instituto dos Professores Públicos da Corte, segundo ofício publicado em $A$ Instrução Pública (14 jul. 1872). A instituição seria uma sociedade literária e beneficente, mas naquele momento, segundo o documento, quando os estatutos estavam quase concluídos, uma "mão invisível espalhou a cizânia entre os obreiros da nossa regeneração”, sendo preciso adiar o projeto.

Em meio a este debate na imprensa, Pardal também teve a iniciativa de convocar professores para reuniões semanais, sob sua presidência, para discutir os temas das Conferências Pedagógicas (A Reforma, 01 dez. 1872; A Instrucção Pública, 08 dez. 1872). A ocorrência das reuniões fica evidente na fala dos professores que nelas compareceram, como o de Antonio Candido Rodrigues Carneiro, que menciona o fato durante a apresentação de seu trabalho nas Conferências de 1873. Tal agência permitia os professores a transmissão de cultura como estratégia de sobrevivência no exercício docente, realizar traduções e deslocamentos culturais para elaboração de discursos a serem apresentados estrategicamente nas conferências.

O Regulamento das Conferências Pedagógicas de 1872 definiu que todos os professores públicos das escolas primárias da Corte seriam reunidos para discutir temas da instrução, "expondo as observações que hajam colhido de sua prática e da leitura das obras que hajam consultado”, demonstrando que no evento haveria espaço para falar de suas experiências em sala de aula. Previsto para acontecer duas vezes por ano, com três dias consecutivos, o que nem sempre se dava, ocorreu até o final da década de 1880.

As Conferências Pedagógicas foram objeto de análise em outro momento no qual procurei examinar suas condições de aparecimento e funcionamento a partir do Regulamento de 1872 (Borges, 2005 e Borges e Gondra, 2005). O enfoque foi, por um lado, pensar a ação do governo imperial ao impor um dispositivo que pretendia homogeneizar a classe docente, tendo em vista a busca de um modelo ideal de professor e os problemas decorrentes de uma profissionalização 
que se dava de diferentes formas; por outro, refletir como os professores reagiram à imposição de participar do evento.

Nesse momento, pretendo realizar uma análise centrada nas Conferências de 1873 a fim de entender um outro aspecto relacionado ao evento: como os professores usaram esse espaço, como fizeram suas exposições e quais foram as ideias apresentadas - algumas das quais não condiziam, intencionalmente, com a pauta do evento.

Os pontos do programa das conferências eram divulgados previamente, sob a forma de perguntas. ${ }^{18} \mathrm{~A}$ presença nas conferências era obrigatória para todos os professores públicos primários da Corte, mas não a exposição de trabalhos. Tal fato singulariza aqueles sujeitos que desejavam divulgar suas ideias pedagógicas, muitas das quais apareciam em outros espaços de exposição. O professor Costa e Cunha, por exemplo, ao querer se concentrar mais em uma discussão, afirma que não vai tratar a respeito dos métodos, pois alegava que:

[...] tendo além disso escrito diversas vezes sobre essa matéria, quer em exposições à inspetoria geral, pela imprensa pedagógica, fundando as minhas opiniões nos princípios que acabo de expender, reporto-me, para o mais que eu aqui poderia dizer, àqueles escritos e passo a outra matéria (Relatório da IGIPSC, anexo 8, p. 12).

Entre os professores que apresentaram trabalhos em 1873, se encontram, resumidamente: Augusto Candido Xavier Cony, que abordou, entre outros assuntos, o sistema Rapet aplicado na França e apresentou um catálogo de livros, de autoria de diversos professores públicos da Corte, para o ensino nas escolas; Manuel José Pereira Frazão, que leu um documento assinado por 35 professores

${ }^{18}$ Pontos do programa das Conferências de 1873: 1) Qual a melhor distribuição das matérias relativas à instrução moral e religiosa, leitura e escrita, noçôes de gramática portuguesa, princípios elementares de aritmética e sistema métrico decimal segundo as necessidades atuais da escola, de modo que saiba o professor pelo programa dessa distribuição qual a tarefa de cada dia útil de antemão preparada?; 2) Em quantos anos poderá o curso das ditas matérias ser percorrido, de maneira que o aluno seja dado por pronto na forma do regimento das escolas?; 3) Se convém ou não a instituição das escolas mistas de instrução primaria?; 4) Qual o método mais racional, simples e eficaz dentre os atualmente conhecidos, para o ensino das primeiras letras e da caligrafia nas escolas primárias? Dado o caso de haver efetivamente um que tenha alguma superioridade sobre os outros, convirá que seja adotado exclusivamente nas aulas públicas?; 5) Qual o meio mais simples para fazer compreender aos meninos o mecanismo do sistema métrico, sem recorrer aos cálculos aritméticos? 
e citou artigo publicado no periódico $A$ verdadeira instrução pública, de 30 de julho de 1872; Antonio Estevão da Costa e Cunha, que trouxe experiências dos Estados Unidos, autores nacionais e estrangeiros e relatórios das províncias para legitimar sua argumentação; Gustavo José Alberto, que citou as experiências das escolas normais da Bahia, onde se formou, e de Paris, enfatizando o uso do "Método Sarrazin"; Antonio José Marques, que apresentou reflexões contidas em compêndio de sua autoria; Antonio Candido Rodrigues Carneiro, que citou prática pedagógica na França e se apoiou na sua experiência para fazer a exposição do quinto ponto de acordo com o combinado em uma reunião prévia entre seus colegas; Francisco Alves da Silva Castilho, que apresentou seu método de ensino; Antonio Ignácio de Mesquita, que apresentou um texto extenso, tomando como partida a antropologia, para fazer um estudo sobre o homem intelectual, moral e físico, usando para isso vários pensadores; Olympio Catão Viriato Montez, que citou países estrangeiros e também usou dados estatísticos; Philippe de Barros e Vasconcellos, que falou sobre o aparelho inventado por Mr. Level, professor francês, e sobre o sistema Lhomond; Antonio Cypriano de Figueiredo Carvalho, que, para tratar de métodos de ensino de primeiras letras, referiu-se a experiências de países como França, Estados Unidos e Suíça; Candido Matheus de Faria Pardal, um dos signatários do texto lido por Frazão, que apresentou um plano de ensino baseado no "sistema Rapet".

Fica evidente nos trabalhos apresentados que os professores reivindicaram autonomia no exercício do ofício. O professor Costa e Cunha enfatiza que, "quanto ao modus docendi", "é prejudicial ao ensino a imposição de qualquer método" (Relatório da IGIPSC, anexo 7, p. 4). Outro aspecto é a ênfase na necessidade de realizar "pesquisas". Esse termo não é usado pelos professores, mas as ações e procedimentos sugeridos por eles inferem a intenção de realizar uma espécie de "investigação científica”, a fim de construírem um conhecimento em torno de diversos aspectos da instrução. Costa e Cunha, por exemplo, solicita o prazo de um ano para organizar e ensaiar um programa para a escola. Para tornar legítimo seu pleito, recorre ao Sr. Rapet, que foi inspetor da instrução de Paris e levou oito anos para produzir um trabalho sobre o assunto (Relatório da IGIPSC, anexo 8, p. 8).

Costa e Cunha também chama atenção para a necessidade de estabelecer "um limite de significação, como já tive ocasião de dizer alhures, aos vocábulos sistema, método, processo, meio, modo, forma, etc. de ensino, que se confundem frequentemente, acarretando com essa confusão dificuldades práticas" (Relatório 
da IGIPSC, anexo 8, p. 11, grifos do autor). Embora os professores reivindicassem autonomia, não significava que também não tivessem necessidade de problematizar e definir conceitos com os quais pudessem operar. $\mathrm{O}$ rigor no uso dos termos era uma premissa para a boa execução da tarefa pedagógica, posto que a confusão entre eles poderia gerar mais um esvaziamento da prática do que ações pedagógicas eficazes.

Outra estratégia usada pelos professores era expor uma ideia mesmo que ela não estivesse na pauta do programa, com intuito de marcarem uma posição política, proferirem uma crítica ou reivindicação, explicitarem algo que desejavam tornar público a fim de denunciar ou de conferir prestígio a si mesmo. Nesse sentido, Costa e Cunha, na parte em que trata da organização das escolas, aproveita para criticar e apontar como o número de alunos interfere na resposta das duas primeiras questões da conferência: "nada é mais funesto do que essas escolas com elevadíssimo número de alunos, essas espécies de manufaturas da educação" (Relatório da IGIPSC, anexo 8, p. 14).

O professor Brazil também inclui uma reflexão sobre a educação moral para, no interior dela, reivindicar melhor remuneração para os professores:

Porém, para o bom desempenho de sua missão, falta ao professor público da capital do império uma das condições essenciais à sua classe: não lhe falta boa vontade, instrução, sistema de ensino nem método; mas falta-lhe o sossego do espírito e a independência devida a sua posição social. [...] remunerai convenientemente o magistério primário, para que os professores se possam dedicar exclusivamente a sua missão, e teremos alcançado tudo (Relatório da IGIPSC, anexo 10, p. 8).

Olympio Catão Viriato Montez atrela uma crítica na abertura da apresentação - que se inicia com a regra de etiqueta da época de demonstração de humildade -, ao destacar sua dificuldade em realizar a reflexão solicitada, pedindo benevolência aos "conspícuos e ilustrados varões":

[...] porque as frases por mim enunciadas são frutos de uma mesquinha inteligência pois que distante doze léguas da corte não tenho podido cultivá-la, além disto a escola sob meu magistério não possui uma biblioteca onde pudesse consultar, não podendo, ainda por essa razão, apresentar senão um imperfeito trabalho, filho da prática de nove anos do magistério (Relatório da IGIPSC, anexo 12, p. 3). 
É possível ver, nesse caso, um recurso à estratégia discursiva, pois qual seria o motivo de um professor insistir em apresentar um trabalho que julga ruim se havia a opção de apenas assistir ao evento? A falta de biblioteca emerge como uma provocação, cuja gravidade se refletiria na impossibilidade de realizar um trabalho com a qualidade esperada, mas, não obstante os entraves, professor não deixa de fazê-lo e de registrar que foi elaborado a partir de sua experiência de nove anos. A eloquência do professor ao longo da apresentação foi bem-sucedida visto que lhe rendeu destaque nos relatórios da Inspetoria.

A estratégia usada remete a uma situação ocorrida com Pardal. Tendo sido notificado em 1871 a dar informações sobre cinco quesitos - sendo o último "quais as exigências do ensino público na escola sob meu magistério" -, o professor respondeu com nove itens (AGCRJ, códice 11.3.28, 27/01/1871, f.7-8). Ao responder os quesitos, Pardal também tratava de informar o que deveria ser feito. Para Bhabha (1998, p. 48, grifo do autor), "a pergunta 'O que deve ser feito?' tem de reconhecer a força da escrita, sua metaforicidade e seu discurso retórico, como matriz produtiva que define o 'social' e o torna disponível como objetivo da e para ação”. Ao escrever um documento que havia sido cobrado a fazer enquanto subalterno do governo, o professor marca sua posição e opera um deslocamento, do lugar de subordinado para a posição de autoridade no ensino. Bhabha (1998, p. 53) sugere que a "posição é sempre um processo de tradução e transferência de sentido” . E o lugar de onde Pardal e Montez discursavam havia sido construído por uma série de agências que conferiam a eles a possibilidade de encarnar diferentes papéis e se deslocar conforme o jogo político.

Tais procedimentos caracterizam uma espécie de agência discursiva e colocam as conferências no lugar de enunciação, estrategicamente ocupado pelos professores. Bhabha (1998) assinala que o "enunciativo" é um processo que tenta rastrear deslocamentos e realinhamentos resultantes de antagonismos e articulações culturais "subvertendo a razão do momento hegemônico e recolocando lugares híbridos, alternativos, de negociação cultural”. Dessa maneira, as conferências, nas quais foram possíveis observar posições antagônicas quanto de articulação, também poderiam funcionar como lugar de negociação cultural e de tradução, com a vantagem de que o lugar de sujeito enunciativo poderia ser ocupado pelo professor. Elas resultariam, segundo Bhabha, na inserção da agência no discurso.

Outro recurso usado pelos professores era o de se reunirem antes do evento para discutirem os pontos, assim como respondê-los coletivamente. O professor 
Pardal presidiu reuniões semanais para estudar o programa, conforme assinalado. No ano de 1873, um trabalho coletivo foi lido pelo professor Frazão, ${ }^{19}$ relator do texto assinado por dezessete professores e por dezoito professoras. O texto, ao mesmo tempo em que responde às questões das conferências, apresenta críticas e reivindicações. Nele, enfatizam a situação dos professores da Corte; criticam o fato de não terem um mês de férias como os "professores da província do Rio de Janeiro"; reclamam da carga de trabalho que não permite descansar e estudar; do salário; e da forma como os são tratados, com desconfiança, sendo acusados de falta de zelo: "Permita V. Ex. que lhe digam os abaixo-assinados com a franqueza de quem se acha profundamente magoado em seus brios: esse modo de tratar aos professores é desanimador, e importa uma verdadeira desconsideração, com que o país nada tem a ganhar" (Relatório da IGIPSC, anexo 20, p. 5).

Interessante observar que, frequentemente, os professores asseveraram nos trabalhos a necessidade de se realizarem estudos e a importância de não se impor ao professor o uso de um método, sinalizando, dessa forma, o valor que atribuíam à autonomia do professor em sala de aula. Algo que parece caro aos docentes, a autonomia para definir práticas, expor ideias e configurar um campo, remete ao exercício de uma intelectualidade que pretendem preservar, diante das intervenções decorrentes das políticas do Estado Imperial. Usufruir de certa autonomia e, ao mesmo tempo, não ter independência na realização do seu trabalho fazem parte das ambiguidades levantadas por Nóvoa (1991) em torno do estatuto dos professores na segunda metade do século XIX. A ideia de autonomia do professor também pode ser vista como uma tradição. $\mathrm{O}$ estatuto de autonomia que os docentes defendem como inerente ao exercício da profissão remete às três categorias de tradições inventadas, pois simbolizam a "coesão" de um grupo, pretendem legitimar um status e uma autoridade, bem como socializar ideias e sistema de valores (Hobsbawm, 2002).

Também cabe destacar Sirinelli (2003) ao abordar o caráter polissêmico da noção de intelectual, o aspecto polimorfo do meio dos intelectuais e a imprecisão recorrente destes. $\mathrm{O}$ autor defende uma definição de geometria variável da qual decorrem duas acepções de intelectuais não autônomas entre si: uma ampla, englobando criadores e mediadores culturais, e outra estreita, baseada na

${ }^{19} \mathrm{O}$ professor Cony em artigo do jornal A Instruçâo Pública, de 15 de abril 1873, questiona a validade do documento, alegando que Frazão, ao elaborar o texto, teria colocado questôes com as quais alguns professores e professoras não concordariam se o tivessem lido. 
noção de engajamento, que segundo modalidade específica inclui, por exemplo, a assinatura de manifestos.

Schueler (2008a), no caso da Corte, e Boto (2003), no caso de Portugal, partilham da compreensão do professor primário como parte de um grupo específico de intelectuais, apesar da diversidade de suas trajetórias pessoais e profissionais, cujo processo de formação consta da própria constituição da cultura escolar, abarcando saberes, práticas de ensino, mas também os gestos e as feições, as formas de agir e de se comportar no cotidiano escolar. Schueler (2008a, p. 135) defende que os professores da Corte na segunda metade do século XIX “atuaram como intelectuais urbanos, como intelectuais do ensino, envolvidos com as questões da instrução primária, do ofício docente e da cidade". Para a autora, eles se destacaram tanto pela produção escrita como obras didáticas, poesias, poemas, livros, artigos para a imprensa e memórias, quanto pela participação nos grupos de sociabilidade intelectual e política da cidade.

Nesse sentido, a fim de legitimarem sua competência intelectual, os professores, durante as conferências, lançaram mão de diversas estratégias discursivas, como citação de autores estrangeiros, relato de experiências de outros países e a referência aos seus próprios colegas, mencionando livros, compêndios, métodos, materiais elaborados por eles. Um modo de conferir legitimidade ao que é produzido no interior da própria classe, um reconhecimento endógeno em busca do reconhecimento exógeno (Sirinelli, 1998).

Igualmente, procuravam mostrar que eram aqueles que, por meio da instrução do povo, poderiam ser responsáveis pelo progresso do país, colocando-o rumo à civilização. Tal discurso, emanado por diversos setores da sociedade, ajudava a constituir a própria profissão docente. Tal postura parece similar a uma análise de Bobbio (1997) em relação aos intelectuais, convencidos de serem um grupo autônomo acima das classes, a eles é atribuída uma tarefa única e extraordinária, o que, no caso dos professores, poderia ser formar o povo civilizado.

Tais agências discursivas não constituem ações de caráter meramente individual, mas sim refletem o espírito de uma corporação que procurava se organizar e se estabelecer como tal, apesar da existência de diferentes grupos, das disputas internas pela representação da classe, das divergências de teor educacional ou político (Villela, 2002a e 2002b; Lemos, 2006 e Vicentini e Lugli, 2011). Constituíam, assim, uma agência coletiva. Para isso, articulavam alianças com diferentes setores da sociedade, debates por meio da imprensa, escrita e publicação de obras didáticas ou literárias, muitas vezes com seus próprios 
recursos, inserção em outros espaços de sociabilidades como grêmios, clubes e associações de diversos tipos, o que parece constituir condição para exercício de uma atividade intelectual, como assinala Schueler (2008a).

Após o término das Conferências de 1873, o inspetor geral Homem de Mello assinalou que os "trabalhos exibidos revelam muito estudo, prática esclarecida e conhecimento dos métodos de ensino nas nações mais adiantadas, tornando-se alguns notáveis pela erudição que neles transluz e faz muita honra aos seus autores" (Relatório da IGIPSC do ano de 1872, assinado em 24 mar. 1873, p. 12). E o Conselho Diretor declarou "dignos de distinção, revelando estudo, zelo e dedicação no desempenho de suas funções no magistério primário" os professores: Costa e Cunha, Mesquita, Marques, Cony, Pardal, Castilho, Gustavo Alberto, Viriato Montez e Phillipe de Barros. Cabe destacar que no ano seguinte ao da Primeira Conferência, dentre esses professores, Costa e Cunha, Cony, Marques e Montez iriam aparecer na lista de professores da Escola Normal Particular da Corte criada em 1874.

\section{"Sob pena de perder a cadeira..."}

Em 1879, ano em que Pardal foi exonerado do cargo de diretor das escolas municipais, um novo ordenamento jurídico seria instituído pelo liberal Leôncio de Carvalho, produzido no calor dos debates políticos e sociais da época. Em 1880, a Escola Normal da Corte começou a funcionar, em meio a um "processo de mudança na concepção sobre a preparação de professores primários, juntamente com as teorias científicas que circulavam na época" (Uekane, 2016, p. 31). Com o Regulamento de 1881, segundo Uekane (2016, p. 33), "os alunos aprovados com distinção em todas as matérias poderiam ser nomeados para cadeiras públicas, sem prestar novas provas de capacidade”. Em 11 de agosto de 1883, o governo baixou o Decreto n. ${ }^{\circ} 8985$, estabelecendo para o professor nomeado um prazo de quatro anos para apresentar diploma pela Escola Normal, sob pena de perder a cadeira. Em 1883, outro regimento interno foi elaborado para as escolas primárias. Também ocorreu nesse período uma série de eventos pedagógicos, como conferências e exposições. Outros professores foram nomeados para as cadeiras, muitos quais não eram nascidos quando Pardal foi nomeado em 1837. 
Quadro 9 - Professores nomeados na década de 1880. Os nomes em itálico indicam os que haviam sido adjuntos

\begin{tabular}{|c|l|c|l|}
\hline N. & Professor & $\begin{array}{c}\text { Ano de } \\
\text { nomeação }\end{array}$ & Observações \\
\hline 1 & Lino dos Santos Rangel & 1880 & - \\
\hline 2 & Guilherme Joaquim da Rocha & 1880 & - \\
\hline 3 & Adolpho Pereira dos Santos & 1880 & - \\
\hline 4 & Januário Santos Sabino Junior & 1881 & Falecido em 22/12/1887 \\
\hline 5 & $\begin{array}{l}\text { Francisco Antonio Castorino de } \\
\text { Faria }\end{array}$ & 1881 & - \\
\hline 6 & Joaquim Dantas de Paiva Barbosa & 1881 & - \\
\hline 7 & José Antonio Gonçalves Junior & 1881 & - \\
\hline 8 & $\begin{array}{l}\text { Adalberto Octaviano Arthur de } \\
\text { Siqueira Amazonas }\end{array}$ & 1881 & - \\
\hline 9 & Antonio Hilário da Rocha & 1881 & - \\
\hline 10 & Felizardo Ildefonso Pereira Alves & 1881 & Falecido em 1885 \\
\hline
\end{tabular}

Fonte: Quadro elaborado pela autora com base nos relatórios da IGIPSC, documentos manuscritos do AGCRJ e no Almanak Laemmert.

Quadro 10 - Professoras nomeadas na década de 1880. Os nomes em itálico indicam os que haviam sido adjuntos

\begin{tabular}{|c|l|c|l|}
\hline N. & Professora & $\begin{array}{c}\text { Ano de } \\
\text { nomeação }\end{array}$ & Observaçóes \\
\hline 1 & Felisdora America da Rocha e Souza & 1881 & - \\
\hline 2 & $\begin{array}{l}\text { Carolina Gabriela de Paula Dias } \\
\text { Carolina Dias da Silva Braga }\end{array}$ & 1881 & - \\
\hline 3 & Josephina de Medina Coeli Barboza & 1881 & $\begin{array}{l}\text { Nomeada para escola de meninos de Santa } \\
\text { Cruz. }\end{array}$ \\
\hline 4 & $\begin{array}{l}\text { Florisbella Moratório de Azambuja } \\
\text { Neves }\end{array}$ & 1881 & $\begin{array}{l}\text { Nomeada para escola de meninos da } \\
\text { Sagoa; Nomeada para escola de meninos de }\end{array}$ \\
\hline 5 & $\begin{array}{l}\text { Rozalina Frazão } \\
\text { Rosalina Cardoso da Silva Campos }\end{array}$ & 1881 & $\begin{array}{l}\text { Entre } 1877 \text { e } \\
\text { Thereza de Jesus Pimentel }\end{array}$ \\
\hline & Thereza Pimentel do Amaral & $\begin{array}{l}\text { Recebeu diploma da escola normal; } \\
\text { Nomeada para escola de meninos da Ilha do } \\
\text { Governador. }\end{array}$ \\
\hline
\end{tabular}




\begin{tabular}{|c|c|c|c|}
\hline 7 & $\begin{array}{l}\text { Amélia Augusta Fernandes } \\
\text { Amélia Fernandes da Costa }\end{array}$ & 1883 & $\begin{array}{l}\text { Nomeada para escola de meninos de Guara- } \\
\text { tiba (1 } 1^{\text {acad. }} \text { ); } \\
\text { Exonerada do cargo de professora da escola } \\
\text { da Candelária por não se enquadrar no } \\
\text { Decreto n. } 8985 \text {, sendo no dia seguinte } \\
\text { nomeada adjunta efetiva. Obteve a habili- } \\
\text { tação na Escola normal e foi reintegrada a } \\
\text { cadeira em } 2 / 05 / 1889 \text {. }\end{array}$ \\
\hline 8 & Adelina Doyle Silva & 1883 & $\begin{array}{l}\text { Apresentou habilitação pela Escola Normal } \\
\text { e por isso foi considerada professora efetiva } \\
\text { (Relatório do Ministro do Império de } \\
\text { 1888). }\end{array}$ \\
\hline 9 & $\begin{array}{l}\text { Maria Elvira de Figueiredo Teixeira } \\
\text { da Fonseca }\end{array}$ & 1883 & Recebeu diploma da escola normal. \\
\hline 10 & Ana Dias Vieira & $\mathrm{AL}, 1884$ & - \\
\hline 11 & $\begin{array}{l}\text { Josephina Carlota Paulina Castagnier } \\
\text { Josephina Castagnier Ferreira }\end{array}$ & 1884 & Faleceu em 1884/1885 (relatório de 1884). \\
\hline 12 & Amélia Frazão de Araújo Cabrita & 1885 & Exonerada em 25/01/1889. \\
\hline 13 & Maria Dias França & 1885 & $\begin{array}{l}\text { Apresentou habilitação pela Escola Normal } \\
\text { e por isso foi considerada professora efetiva } \\
\text { (Relatório do Ministro do Império de } \\
\text { 1888). }\end{array}$ \\
\hline 14 & $\begin{array}{l}\text { Stella Nahon } \\
\text { Stella Lindheimer (1888) }\end{array}$ & 1885 & Recebeu diploma da escola normal. \\
\hline 15 & Maria Amélia Fernandes & 1885 & $\begin{array}{l}\text { Recebeu diploma da escola normal; } \\
\text { Falecida em } 1884 .\end{array}$ \\
\hline 16 & Angelina Sandoval Castrioto Pereira & 1885 & Recebeu diploma da escola normal. \\
\hline 17 & Maria José de Medina Coeli Ribeiro & 1885 & 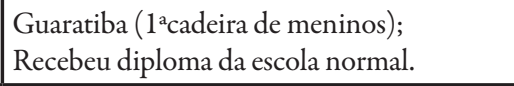 \\
\hline 18 & Catharina Mattoso Forte da Silva & 1885 & $\begin{array}{l}\text { Paquetá (meninos); } \\
\text { Recebeu diploma da escola normal. }\end{array}$ \\
\hline 19 & Olympia Francisca Proença & 1885 & Exonerada em 17/07/1886. \\
\hline 20 & Virginia Pinto Cidade & AL, 1886 & - \\
\hline
\end{tabular}

Fonte: Quadro elaborado pela autora com base nos relatórios da IGIPSC, documentos manuscritos do AGCRJ e no Almanak Laemmert.

Chama atenção nos quadros a diminuição do número de professores homens que entraram e a nomeação de várias professoras para escolas do sexo masculino. Algumas professoras nomeadas na década anterior para escolas de meninas, ao serem removidas, também foram atuar em escolas de meninos. No 
entanto o ingresso das mulheres em tais cadeiras não se deu sem a resistência dos professores homens que, conforme estudo de Guimarães (2011), "não abandonaram passivamente o magistério primário”, criticando a postura do governo em favorecer a regência das mulheres nas escolas do sexo masculino. Nesse sentido, a autora assinala que o processo de feminização do magistério não se deu sem disputas no interior do próprio campo da educação.

A maior parte dos professores nomeados, homens e mulheres, que constam nos quadros continuaram pertencendo ao grupo dos que haviam sido adjuntos. Vários deles eram parentes de professores regentes como Sabino, Amazonas, Frazão, Coeli. Entretanto, por causa das exigências do decreto de 1883, várias professoras que tinham sido adjuntas adquiriram o diploma da Escola Normal e a ameaça de perder a cadeira se concretizou em pelo menos um caso, o de Amélia Augusta Fernandes, "reclassificada" como adjunta até que obtivesse o diploma, o que ocorreu em 1889.

Nessa listagem de professores que entraram no magistério público após a exoneração de Pardal, ainda podemos observar resquícios de sua atuação no ensino de primeiras letras. Ao menos um dos professores, Lino dos Santos Rangel, havia sido seu aluno na Escola Pública da freguesia de Santa Rita. De uma forma geral, nota-se que uma significativa quantidade de professores públicos haviam passado pelo exame de Pardal, seja na condição de adjuntos ou nos concursos públicos, o que mostra que o professor tinha uma parcela de responsabilidade na configuração docente das escolas públicas da Corte. Responsabilidade e agência que obviamente compartilhava com outros colegas.

Poucos professores passaram pela experiência de acompanhar, em serviço, tantas mudanças como o professor Pardal. Da instituição do ensino mútuo, passando por reformas e normatizações, ensino simultâneo, formação pela prática, conferências pedagógicas, criação das escolas municipais, a criação de escolas normais, juntamente com as questões políticas e sociais de cada época e acompanhando e agenciando a construção de relações com governo ao longo do tempo.

Neste capítulo, foi possível acompanhar um conjunto de relações de características distintas que afetaram a docência de forma variada. Relações construídas e fortalecidas no interior da própria escola, relações enfraquecidas pelas desavenças e intrigas políticas, relações resistentes mantidas pela força da tradição, relações coletivas construídas pela identidade em comum, que conferiam aos professores tanto admiração quanto desonra, insatisfação, e que por sua vez resultavam em elogios, gratificações, acusações e exonerações por parte do 
governo. Relações que provocavam debates, mudavam decisões, interferiam no funcionamento da profissão docente e das escolas e que permitiram acompanhar agências docentes.

No meio da trama de relações, observamos que as etapas burocráticas, advindas dos anos de atividade, constituem momentos singulares na constituição do ofício e na inserção dos professores na cidade, como veremos no capítulo III, assim como proporcionam a elaboração de uma experiência na administração de suas trajetórias. Trajetórias com tempos e espaços distintos, numa cidade, como diz Chalhoub (2006), "febril" em vários sentidos, encerradas de diversas formas, por mudanças de vida, permutas, exonerações, jubilações e morte em serviço. 